Misunderstood Gestures: Iconatrophy and the Reception of Greek Sculpture in the Roman Imperial Period Author(s): Catherine M. Keesling

Reviewed work(s):

Source: Classical Antiquity, Vol. 24, No. 1 (April 2005), pp. 41-79

Published by: University of California Press

Stable URL: http://www.jstor.org/stable/10.1525/ca.2005.24.1.41

Accessed: $21 / \overline{/ 02 / 2012 ~ 12: 13}$

Your use of the JSTOR archive indicates your acceptance of the Terms \& Conditions of Use, available at http://www.jstor.org/page/info/about/policies/terms.jsp

JSTOR is a not-for-profit service that helps scholars, researchers, and students discover, use, and build upon a wide range of content in a trusted digital archive. We use information technology and tools to increase productivity and facilitate new forms of scholarship. For more information about JSTOR, please contact support@jstor.org. 


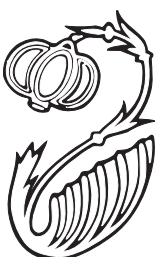

\title{
Misunderstood Gestures: Iconatrophy and the Reception of Greek Sculpture in the Roman Imperial Period
}

\begin{abstract}
Anthropologists have defined iconatrophy as a process by which oral traditions originate as explanations for objects that, through the passage of time, have ceased to make sense to their viewers. One form of iconatrophy involves the misinterpretation of statues' identities, iconography, or locations. Stories that ultimately derive from such misunderstandings of statues are Monument-Novellen, a term coined by Herodotean studies. Applying the concept of iconatrophy to Greek sculpture of the Archaic and Classical periods yields three possible examples in which statues standing in Greek sanctuaries may have inspired stories cited by authors of the Roman imperial period as explanations for the statues' identities, attributes, poses, or locations. The statues in question are the portrait of the athletic victor Milo of Croton at Olympia, a bronze lioness on the Athenian Acropolis identified as a memorial to the Athenian prostitute Leaina ("lioness"), and the Athena Hygieia near the Propylaia of Mnesikles.

Inscriptions on the bases of Archaic and Classical statues in Greek sanctuaries typically named the dedicator, the recipient deity, and the sculptor, but did not include the subject represented or the historical occasion behind the dedication. These "gaps" left by votive inscriptions would only have encouraged the formation of iconatrophic oral traditions such as the examples examined in this article.
\end{abstract}

\section{INTRODUCTION}

The study of Greek sculpture-hampered as it is by the near-complete disappearance of bronze originals and the widespread loss of original contextfrequently takes for granted the premise that ancient literary sources accurately convey the appearance, identities, and significance of the statues they describe.

I would like to thank the following for permissions, references, and comments: I. Trianti and C. Vlassopoulou of the First Ephoreia of Classical Antiquities in Athens; N. Vogeikoff and C. Downey in the archives of the American School of Classical Studies at Athens; E. Lupu, B. Millis, O. Palagia, B. S. Ridgway, J. Trimble, and two anonymous readers.

Classical Antiquity. Vol. 24, Issue 1, pp. 41-79. ISSN 0278-6656(p); 1067-8344 (e).

Copyright (C) 2005 by The Regents of the University of California. All rights reserved. Please direct all requests for permission to photocopy or reproduce article content through the University of California Press's Rights and Permissions website at www.ucpress.edu/journals/rights.htm. 
The extent of Classical archaeologists' reliance upon such sources is laid bare when the ancient sources themselves acknowledge competing explanations. In Troizen, Pausanias (2.32.3) saw a statue by the fourth-century sculptor Timotheos that he thought represented Asklepios but that his informants identified as the local hero Hippolytos; on the road to Panopeus (10.4.3), there was a statue identified by some as Asklepios and by others as Prometheus. At Onkeion in Arkadia (8.25.7), Pausanias took to task those who thought that the statue of Demeter Lousia represented Themis. These cases of disagreement, unlike many others in Pausanias' Periegesis, cannot easily be explained as the result of lost inscriptions or the later reinscription of statue bases. ${ }^{1}$ As Dio Chrysostom observed in a speech delivered to the people of Rhodes in the late first or early second century CE (Or. 31.90-93), Greek statues representing gods, heroes, and hemitheoi, unlike portraits, did not normally bear inscribed, identifying name labels. ${ }^{2}$ The evidence of inscribed statue bases from mainland Greece overwhelmingly confirms Dio's distinction. If some examples of competing identifications of statues in Pausanias do not result from the absence of accurate or legible inscriptions, what could be the cause?

In the case of the statue in Troizen, it is tempting to conclude that Pausanias based his identification of Asklepios upon his own iconographic analysis with reference to Panhellenic sculptural types, but that the inhabitants of Troizen reidentified the statue as Hippolytos to fit their own purpose, an assertion of local history and identity amidst the reality of Roman rule. ${ }^{3}$ The fact that Pausanias was separated by as much as 700 years from the period in which the statues he saw were made has not always been considered a problem; but if the statue he encountered at Troizen was several hundred years old, it is possible that its appearance or location had changed over time-for example, through the loss of hand-held attributes or later regrouping with other statues - in a way that encouraged its reinterpretation. In some cases ancient nicknames for Greek statues, typically derived from their poses or hand-held attributes, over time may inadvertently have disguised the statues' original identities. ${ }^{4}$ Another even more unsettling reality about Greek

1. For these and other examples of "competing voices" in Pausanias, see Alcock 1996: 260-65; for Pausanias' oral sources, see most recently Jones 2001. For clearly marked instances of lost or illegible inscriptions and reinscribed statue bases in Pausanias, see Whittaker 1991; Bowie 1996: 223-25; and Kreilinger 1997: 474. Reinscription is likely in the case of the statue in the Argive Heraion called Orestes by the locals but identified by Pausanias as a portrait of Augustus (Paus. 2.17.3).

2. Romans were liable to be accused of misunderstanding the Greek custom: according to Favorinus (Dio Chrys. Or. 37.42), the Roman general L. Mummius inadvertently rededicated a statue of Poseidon from Isthmia to Zeus and inscribed the name label "Zeus" on a portrait of Philip II from Thespiae. For the rededication of votive statues by Mummius, Sulla, and other Romans, see Philipp and Koenigs 1979: 202-203 and Kinney 1997: 136-37. For the use of inscribed name labels for Idealplastik in the late Hellenistic and Roman periods, see Kron 1977: 155-60.

3. On local oral traditions in Pausanias, see Alcock 1996 and Arafat 1996: 49.

4. Polykleitos' Doryphoros may have been intended to represent Achilles (as argued most recently by Stewart 1995: 247-49). Both Pheidias (Pliny HN 34.54) and Euphranor (HN 34.77) 
sculpture is the continuing multivalence of some sculptural types: though the problem of multivalence is most acute for Archaic types such as the marble kouros and kore, it is arguable that some of the Classical sculptural types that still confound modern scholars also lacked a single, uncontested identity recognizable throughout Classical antiquity. ${ }^{5}$

This paper will discuss one particular phenomenon, identified by anthropological literature on oral traditions, that provides some insight into the process of formation of the traditions about Greek statues recorded by sources of the Roman period. Jan Vansina defined iconatrophy as one process whereby oral traditions originate as after-the-fact explanations for remarkable objects that, through the passage of time, have ceased to make sense to their viewers. Such "objects" can be broadly defined to include archaeological sites and monuments in addition to artifacts of everyday life or works of art. Ideally, this process of iconatrophy is to be distinguished from the preservation of authentic historical memories (whether oral or written) in association with objects. Iconatrophic traditions, once they attach themselves to objects, have the potential to reinforce themselves at the expense of competing, more "authentic," traditions with lesser explanatory force; they often function as aetiologies, but are to be distinguished from other aetiological stories by their reference to objects. An iconatrophic tradition can come to be regarded as proven true by the object itself, a type of back-formation or "feedback" frequently encountered in the study of African societies. ${ }^{6}$

The classic example of iconatrophy cited by Vansina is that of Pope Johanna. It is now recognized that the remarkable late medieval tradition of a female pope named Johanna, whose imposture was unmasked when she gave birth during a procession from Saint Peter's Basilica to the Lateran, is based upon the misinterpretation of a series of objects and customs of the papacy no longer self-explanatory at the time the Johanna stories became current: an inscription

made female figures called Kleidouchoi ("keepers of the keys") whose specific identities were not recorded by the literary tradition (Palagia 1980: 40-41 and Mantis 1990: 32-39). The inverse process occurred in the Renaissance when Hellenistic genre figures (such as the Spinario or "thorn-puller") were given specific identities (Barkan 1999: 150-58).

5. On multivalence in Greek sculpture, see Marcadé 1985; for possible examples of fifthand fourth-century female sculptural types used to represent different goddesses, see Baumer 1997: 83-84 (Artemis in the east frieze of the Athena Nike temple based upon the Demeter Capitolina type; same figural type used to represent Hygieia in one votive relief and a nymph in another). Pliny's (HN 36.17) aition for the late fifth-century cult statue of Nemesis at Rhamnous plays upon multivalence and the possibility of confusion: when the sculptor Agorakritos lost a contest with Alkamenes to produce a statue of Aphrodite, he sold his "Aphrodite" to the sanctuary at Rhamnous, where it became the cult image of Nemesis. Agorakritos' Nemesis held a phiale in her right hand and the branch of an apple tree in her left; in later Greek sculpture, Nemesis' typical attributes were wings and a cubit or measuring rod (Shapiro 1993: 173-77 and Palagia 1994: 118-20). For the fragments of Agorakritos' Nemesis found at Rhamnous and their reconstruction, see Despinis 1971: $1-108$.

6. See Vansina 1965: 36-39; Vansina 1985: 10, 44-45, 157-58, and 187-88; and Rosalind Thomas 1989: 176 n. 48 and 199. On feedback, see more generally Henige 1982: 80-87. 
seeming to refer to a pope in the feminine; a statue of a woman dressed like a pope accompanied by a child; an apparent detour in the papal processional route through Rome (to avoid passing the spot where Johanna had given birth); and two Roman marble thrones with holes in the seats used in the ceremonial consecration of new popes in the Lateran (explained as devices used to verify the pope's gender, an expedient made necessary by the experience of Pope Johanna). ${ }^{7}$ Leonard Barkan, in his work on the Renaissance reception of ancient monuments in Rome, calls attention to further examples of iconatrophy involving misunderstandings of the identities, gestures, poses, or attributes of Greek and Roman sculpture. The giant, mirror-imaged "Horse tamers" found on the Quirinal, and inscribed "Opus Fidiae" and "Opus Praxitelis" in late antiquity, were at one point in the Renaissance identified as philosophers or seers named Fidia and Praxiteles, and their pose interpreted as an allegory about the need to "tame" oneself. ${ }^{8}$ A comparable story arising in a Greek milieu is that of the tailor of Porto Raphti. Ancient Koroni in Attica was renamed Porto Raphti ("Bay of the Tailor") after a colossal seated statue of the Roman imperial period mistaken by the medieval inhabitants of the area for a tailor seated on his chair, holding a pair of scissors in his hand. Other ancient statues seen in the area in the eighteenth century were identified by the locals as the tailor's wife and daughter. ${ }^{9}$

I approach the problem of iconatrophy from a perspective inverse to Vansina's, not as an anthropologist concerned with oral traditions but as a student of Greek sculpture. Applying the concept of iconatrophy to Greek sculpture of the Archaic and Classical periods yields several possible examples in which statues standing in Greek sanctuaries may have generated oral traditions cited by written sources of the Roman period as explanations for the statues' identities, attributes, poses, or locations. It is not difficult to understand why the possibility of iconatrophy in the accounts of Greek sculpture recorded by literary sources has not been systematically explored: once this possibility is admitted, it casts doubt upon the authenticity of some ancient stories about Greek statues that Classical archaeologists normally accept at face value. ${ }^{10}$ Yet there are at least two positive outcomes to be gained by recognizing the mechanism of iconatrophy at work in Classical antiquity. The first is to acknowledge that the formation of oral

7. Vansina 1985: 10; Pardoe and Pardoe 1988: 43-52; and most recently Boureau 2001.

8. See Barkan 1993: 134; Barkan 1999: 113-15 and 124-25; and Haskell and Penny 1981: 136-41. Since the Renaissance, the same statues have most frequently been identified as Castor and Pollux on the basis of their iconography. The bronze equestrian portrait of Marcus Aurelius now in the Piazza Campidoglio was thought in the Middle Ages to represent a peasant who saved Rome (Haskell and Penny 1981: 252-55, no. 55).

9. The gender, identity, and precise date of the Porto Raphti colossus have been disputed. Vermeule (1962 and 1976) identified it as a Hadrianic or early Antonine female figure, perhaps holding sheafs of wheat later mistaken for scissors; Miller (1972) reconstructed the figure as an emperor portrait of the late second or early third century CE holding a scepter or spear.

10. The use of anecdotes in ancient sources as historical evidence presents similar problems, as discussed by Saller 1980. 
traditions about ancient monuments is a long-term, continuing process that is in some ways predictable; the second is to lessen the importance of belief, on the part both of the authors who recorded such traditions and of these authors' own informants, in evaluating such traditions. Some stories about statues recorded by our sources may be best understood not literally as authentic survivals from the Archaic and Classical periods, but rather as shared fictions, manifestly untrue but repeated all the same: the point of telling such stories was not to uncover statues' original meanings, but to make surviving monuments of earlier periods in Greek history meaningful, to restore them to significance in the present under Roman rule.

The workings of "deformations" attributable to oral tradition in Herodotus' Histories in the fifth century BCE have already been widely acknowledged and contribute to studies of how his literary aims shaped his material. ${ }^{11}$ Interestingly, the most clear-cut example of iconatrophy in Herodotus is one he claims to have discovered for himself. In the course of the Egyptian logos, Herodotus (2.130-31) gives the following account of a group of twenty nude wooden female figures in the palace of Mycerinus at Saiis: though Herodotus' informants told him that this group of statues represented servant girls who witnessed Mycerinus' incest with his daughter and as a result had their hands cut off by Mycerinus' queen, he himself scoffed at the story and said that he could see some of the statues' hands still lying at their feet, sufficient proof that they had simply decayed with age and fallen off. If we accept the basic premise that neither Herodotus' autopsy of Egypt nor the statues themselves are to be rejected outright as literary fictions, the explanation given by Herodotus' local informants is a good example not only of iconatrophy based upon the damage incurred by statues over time, but also a "Denkmal-" or "Monument-Novelle," a story based entirely upon a misunderstanding of the iconography of a statue or other monument. ${ }^{12}$ A further example elsewhere

11. See especially Murray 1987 (using the term “deformation”) and Murray 2001; Evans 1991: 110-29; Hedrick 1995: 55-64; and Kurke 1999: 175-246. For the primacy of oral traditions (whether “authentic" or not) as Herodotus' sources, see West 1985 and Hedrick 1993.

12. For Denkmäler- and Monument-Novellen in Herodotus' Egyptian logos, see Spiegelberg 1926: 21-27 and Lloyd 1988: 28 (on Hdt. 2.107), 37 (on 2.110), and 80-81 (on 2.130-31). On the role of autopsy, see Marincola 1987. Cf. Fehling (1989: 128-30), who rejects the entire account of the palace at Saïs as a fiction: "The natural conclusion is that the story is Herodotus' own invention." Other possible examples of iconatrophy resulting from Herodotus' or his sources' misunderstanding of non-Greek monuments are: the story that an army of mice helped the Pharaoh Sethos to defeat Assyrian invaders (Hdt. 2.141), possibly inspired by a statue of a man holding a mouse in an Egyptian temple (Spiegelberg 1926: 26-27; West 1985: 297 n. 91, disputed by Fehling 1989: 136-37); the relief associated by Herodotus (3.88) with Darius and his groom Oebares' "horse-trick" to claim the Persian throne (West 1985: 296-97); and Herodotus' idea that the false Smerdis had no ears (Hdt. 3.69), conceivably based upon a statue of the usurper Bardiya mutilated after Darius' accession (West 1991: 176-81). The case of the golden statue at Delphi called Croesus' bread-baker (Hdt. 1.51) is a difficult one: the statue's nickname may be an authentic oral tradition surviving into Herodotus' time (Garrett and Kurke 1994: 80-83), but Plutarch's story (de Pyth. Or. 401e-f) that Croesus' baker saved his life should be a later Monument-Novelle explaining the statue (cf. Parke 1984: 219). 
in Herodotus' Histories demonstrates that icon-atrophic explanations of Greek sculpture were already current in Herodotus' time. This is the story told about the ancient wooden cult images of the goddesses Damia and Auxesia on Aigina (Hdt. 5.86.3-4). The Aiginetans claimed that when the Athenians came to Aigina and tried to drag the two statues away, both fell to their knees and assumed the kneeling pose that they maintained forever afterward. It has been suggested by modern scholars that the Aiginetan cult statues belong to a small class of Greek images representing goddesses giving birth; whether or not this is the case, kneeling statues were extremely unusual in Greek sculpture of every period, and for that reason the poses of Damia and Auxesia required explanation even in the fifth century BCE. ${ }^{13}$

The possibilities of distortion and deformation resulting from the processes of oral tradition have been more widely recognized in Herodotus than in sources of the Roman imperial period writing about Greek sculpture-Pliny, Pausanias, Plutarch, Athenaeus, and Philostratos. I will suggest that the origins of iconatrophic stories about Greek statues recorded by these authors stem not from endemic cross-cultural misunderstanding, but rather from the dedicatory practices of mainland Greek sanctuaries in the Archaic and Classical periods. Before the fourth century BCE, the great majority of the statues dedicated in Greek sanctuaries, regardless of their subjects, were votive: that is, the epigraphic formula inscribed on their bases named the dedicator, and often the recipient deity as well, but not the subject the statue represented. In addition, votive inscriptions of this period seldom specify any occasion behind the dedication beyond formulaic references to vows, tithes (dekatai), and first-fruits (aparchai). ${ }^{14}$ The portrait statues of athletic victors dedicated in the sanctuary at Olympia are exceptions: beginning in the early fifth century, the inscriptions accompanying these statues consistently included the athlete's name, his father's name, his home city, and his athletic event. ${ }^{15}$ In the fourth century BCE, honorific formulas naming the subjects represented by portrait statues began to appear in sanctuaries at the same time that portraits in agoras, theaters, and other civic spaces became common. These honorific formulas-either in the form of "X dedicated [a portrait of] $\mathrm{Y}$ " or of inscribed name labels-provided a new clarity, making it possible for the

13. For the connection between Damia and Auxesia and kneeling representations of childbirth goddesses, see Figueira 1993: 36-37 and 57-58, and Dörig 1993. The kneeling pose for both female and male figures was used frequently in Egyptian sculpture: for examples, see Russmann 1981.

14. For votive inscriptions, see Lazzarini 1976 and 1989-1990.

15. A prose example is the inscription on the base for a portrait statue of the Athenian Kallias Didymiou (Olympic victor in $472 \mathrm{BCE}$ and periodonikes): "Kallias Didymiou Athenaios pankration. Mikon the Athenian made it" (Dittenberger and Purgold 1896: no. 146). The inscription for Euthymos of Locri (victor in boxing in 472 BCE) is a metrical example: "I, Euthymos son of Astykles of Locri, was three times victor at Olympia; he set up this portrait for mortals to look upon. Euthymos of Locri Epizephyri dedicated. Pythagoras of Samos made it" (Ebert 1972: 69-71, no. 16). The name, patronymic, city, and event echo the contents of the victory proclamation at the Olympic games (Day 1994: 63-71). 
readers of statue base inscriptions to determine the subjects of portrait statues. ${ }^{16}$ Honorific formulas for portrait statues appear from the evidence of inscribed statue bases to have been introduced at different times in different sanctuaries; on the Athenian Acropolis, they make their first appearance during the first half of the fourth century BCE. ${ }^{17}$ Votive formulas continued to be used for freestanding statues representing the gods, but sanctuaries such as Delphi and the Acropolis show major declines in the dedication of such statues concomitant with the rise of honorific portrait dedications. ${ }^{18}$

Dedicatory inscriptions were never the only source visitors to Greek sanctuaries used to learn about the statues they saw there, and the existence of a large-scale literate population capable of reading such inscriptions continues to be subject to doubt. Though dedicators who failed to inscribe their names risked being forgotten, associations between dedicators and offerings sometimes endured even in the absence of dedicatory inscriptions: Thucydides (6.54) quotes a faded inscription to support his attribution of the altar in the Pythion in Athens to the younger Peisistratos, and at the same time asserts that Peisistratos also dedicated the altar of the Twelve Gods in the Athenian Agora despite the fact that the dedicatory inscription could no longer be read. At the same time, though, it is important to notice that the votive statue inscriptions typical of the Archaic period and the fifth century in Greek sanctuaries named the dedicator but not the subject the statue represented: the consequence of this practice is a "gap" between the information provided by inscriptions and viewers' desire to know whom or what the statue represented, and when and on what occasion the statue was set up. Such gaps remained even when dedicatory inscriptions were present and legible, and thus the phenomenon of oral traditions filling the gaps is not the result of absent or inadequate dedicatory inscriptions; instead, information that could not be obtained by reading dedicatory inscriptions, such as the subject the statue represented or the occasion for its dedication, was supplied over time by oral traditions. ${ }^{19}$

It has been argued that oral traditions originating in Greek sanctuaries have a greater claim to be authentic than others because priests and other sanctuary personnel were concerned with preserving these traditions accurately: the sixthcentury BCE dedications of Croesus and the other Lydian kings at Delphi continued to be identified and discussed in Herodotus' time, and Plutarch himself was a

16. For honorific portrait statues and their inscriptions, see Lewis and Stroud 1979 and Lazzarini 1984-1985.

17. Examples: IG II $^{2} 3838$ (portrait of Polyllos Polyllidou Paianieus dedicated by his brother Polystratos) and IG II ${ }^{2} 4323 / 4189$ (portrait of Lysimachos Lysitheidou Agrylethen, reinscribed in the first century CE as a portrait of Marcus Licinius Crassus Frugi).

18. For statistics on Acropolis dedications, see Geagan 1996; for the shift to honorific portraits at Delphi, see Jacquemin 1999.

19. Cf. Evans' (1991: 130) comment on local traditions about monuments in Herodotus: "An isolated monument without a legible inscription is a mythopoeic catalyst" (my italics). Rosalind Thomas (1989: 8-10 and 96-108) emphasizes that the formation of oral traditions was a process dependent upon identifiable mechanisms of transmission. 
priest at Delphi in the second century CE. ${ }^{20}$ Such claims come into conflict with the findings of anthropology, which indicate that even relatively "fixed" oral traditions very seldom if ever survive accurate and unchanged for more than 200 years, a far cry from the vast chronological distance of 650 years between Plutarch and Croesus' dedications. Authoritative written records concerning statues and other outdoor monumental dedications available for consultation by priests and other local authorities remain hypothetical before the works of Polemo of Ilion and other late Hellenistic writers on Greek sanctuaries. Polemo himself compiled his account of dedications at Delphi and on the Athenian Acropolis late enough that he probably fixed in writing previously oral traditions about statues in the sanctuaries. Votive statues, unlike the offerings stored in temples, were rarely recorded in inscribed inventories. Even the inscribed Lindian temple chronicle of 99 BCE from Rhodes is entirely retrospective: the Archaic and Classical votive offerings it catalogues and describes no longer existed at the time the chronicle was compiled, and it includes conflicting testimonies about the same offerings. ${ }^{21}$ Another factor that has seldom been taken into account is the possibility of significant damage to statues over time that might prevent them from being recognized, and at the same time encourage aetiological Monument-Novellen comparable to the story in Herodotus about Mycerinus' twenty handless servant girls. It can also be demonstrated that Archaic and Classical statues in some sanctuaries were moved, removed, and regrouped over the course of time. ${ }^{22}$ Each of these circumstances would only have encouraged iconatrophy and other deformations of oral tradition within the context of Greek sanctuaries.

Pausanias and other second sophistic authors showed greater interest in the sculpture of the Archaic and Classical periods than in later monuments. The statistics on this point are telling and clear. At Olympia, Pausanias mentioned far more Archaic and Classical victor monuments than fourth-century, Hellenistic, or Roman ones, while at the same time preserved statue bases indicate that fourth-

20. See, for example, Flower 1991: 66-70 on Croesus' dedications at Delphi and Evans 1991: 130; cf. Murray 1987: 101-102.

21. For the relatively short lifespan of authentic oral traditions, see Murray 1987: 94-99 and Rosalind Thomas 1989: 123-32 and 242. For Polemo, see Davies 2000: 214-16 and Rutherford 2001: 45-47. For the Lindian temple chronicle, see most recently Higbie 2001 and 2003. Gabba's (1981: 60-61) comments on Polemo's Roman successors are instructive: "It seems clear that monuments, statues, toponyms, whose significance was for various reasons unclear, were at first invested with fantastic meanings of different kinds, but always related to legendary episodes or episodes of earliest Roman history; this took place in the context of an antiquarian and guide-book tradition aiming to explain and expound the monuments involved. In a complete reversal of roles, the monuments then became the documents which guaranteed the historicity and credibility of the legends or stories which had grown up."

22. See Kyrieleis (1995: 17-21) for the rearrangement of Archaic votive statues in the Samian Heraion. [Plut.] X oratt. 839d refers to a group of portrait statues representing the orator Isocrates and his family on the Athenian Acropolis; by the Roman imperial period, the statue of Isocrates' mother had been reinscribed and placed near a statue of Hygieia, and the statue of Isocrates' sister had disappeared. 
century and Hellenistic monuments far outnumbered those of earlier periods in the sanctuary. ${ }^{23}$ Pausanias' archaism is apparent in his treatment of the Athenian Acropolis, where nearly all of the portrait statues he mentioned represented fifth-century or earlier subjects, while the great majority of the statue bases for portraits are later in date. It is precisely the monuments of the Archaic period and the fifth century that were potentially the most unstable in their meanings: the inscriptions accompanying these were less informative than the inscriptions on later monuments standing in the same sanctuaries. ${ }^{24}$ Moreover, the older the statues were, the more likely they were to have been damaged, repaired, reinscribed, moved, or even replaced at some point in their history.

In the remainder of this article, I will examine three possible examples of iconatrophy involving statues dedicated in Greek sanctuaries. The precise dates of the first two examples - the portrait statue of the athletic victor Milo of Croton at Olympia and the bronze statue of a lioness ("Leaina") on the Athenian Acropoliscannot be determined because the statues' inscribed bases have not been preserved, but strong cases can be made for dating both before the end of the fifth century BCE. The first statue is a portrait, the second represents an animal, and the third-the statue of Athena Hygieia on the Athenian Acropolis-is a divine image. All three are the subjects of stories reported in some form by multiple authors of the Roman imperial period (first through third centuries CE). The main sources we have for such stories - the Elder Pliny, Pausanias, Plutarch, and Athenaeus-made use of earlier, chiefly Hellenistic, written sources such as Polemo whose contribution is difficult to measure because they survive only in small fragments. Though it is impossible to say to what extent the dynamic processes of oral tradition had already affected Polemo in the Hellenistic period, the Roman imperial sources have the advantage of giving a two-hundred-year window on the status of these traditions, continually reinforced by the statues themselves.

\section{MILO OF CROTON AT OLYMPIA}

The wrestler Milo of Croton was five times periodonikes, and is reputed to have won a total of six victories at Olympia, six at Delphi, ten at Isthmia, and nine at Nemea. Not only was his athletic career in the second half of the sixth century BCE particularly durable, but so was his fame: stories about him feature prominently in a wide variety of sources dating to the Roman imperial period, nearly 700 years after his death in the late sixth or early fifth century BCE. ${ }^{25}$

23. Herrmann 1988: 123-29. For literary archaism in general, see recently Whitmarsh 2001: 41-89.

24. For instability in the meanings of monuments in general, see Alcock 2001b: 327-28.

25. For the athletic career of Milo, see especially RE XV.2 (1932) s.v. Milon (2) (A. Modrze): 1672-76; Moretti 1957: 72-74; Ebert 1972: 182-85, no. 61; and Maddoli, Nafissi, and Saladino 1999: 274-77. Apart from Pausanias 6.14.5-8 and Philostratos VA 4.28, the most important sources are Athen. 10.412e (feats of appetite, including carrying a bull around the stadium at Olympia and 
Pausanias' account (6.14.5-8) begins with an explicit reference to a portrait statue of Milo in the Altis at Olympia. Neither the portrait at Olympia nor any other ancient portraits identifiable as representations of Milo survive. In keeping with one of Pausanias' typical narrative methods, the statue at Olympia occasions the biographical remarks that follow, which are worth quoting extensively:

Milo the son of Diotimos was made by Dameas, himself from Croton.... It is also said that Milo carried his own statue into the Altis. His feats with the pomegranate and the discus are also recounted. He held a pomegranate in such a way that no one could wrest it from him by force, and yet he did not damage it by pressure. He would stand upon an oiled discus laughing at those who charged him and tried to push him from the discus. He used to perform also the following feats for show. He would tie a cord around his forehead as if it were a taenia or a stephanos. Holding his breath inside his mouth and filling with blood the veins in his head, he would break the cord by the strength of these veins. It is said that he would let down by his side his right arm from the shoulder to the elbow, and stretch out straight the arm below the elbow, turning the thumb upwards, while the other fingers were arrayed in a row. In this position, then, though the little finger was lowest, no one could bend it back by pressure. ${ }^{26}$

Milo's first extraordinary feat of strength was to carry his own portrait statue (andrias) into the Altis; as Joseph Fontenrose has pointed out, a similar story attached itself to the contemporary Olympic victor Theogenes of Thasos, who as a child supposedly removed from its base and carried home the statue of a god in the agora of Thasos. ${ }^{27}$ This and the two feats of strength that follow,

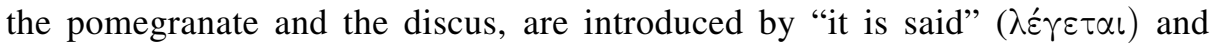
thus explicitly marked as testimony neither read directly from an inscription nor endorsed by Pausanias as authoritative narrator. Unlike Athenaeus and other Greek authors of the Second Sophistic, Pausanias seldom cites the works of other authors as his sources, reinforcing the presumption of autopsy and oral testimony throughout the Periegesis. ${ }^{28}$ Though feat number four-the cord (chorde)-is not introduced by $\lambda \varepsilon^{\prime} \gamma \varepsilon \tau \alpha$ l, the feat of the unbendable right hand that follows is, and the whole series of Milo's five feats of strength leads into a description of Milo's death introduced by "they say" ( $\varphi \alpha \sigma i \nu)$.

then eating it in a single day); Pliny $H N 7.20$ and 37.144 (feats of strength: no one could dislodge Milo from his spot and no one could straighten his finger when he held an apple); Aelian VH 2.24 and NA 6.55 (feats of strength: when Milo held a pomegranate in his hand, none of the other competitors could remove it, but his girlfriend [erômenê] could do so easily); DS 12.9 (Milo fought with the Crotoniates against Sybaris in 511/10 BCE); Strabo 6.1.2; Val. Max. 9.12.9; and Gell. NA 15.16 (Milo's death).

26. Trans. W. H. S. Jones (modified).

27. Fontenrose 1968.

28. See especially Arafat 2000: 194 and Davies 2000. For Pausanias' use of inscriptions as sources, particularly at Olympia, see Habicht 1984: 55-56. 
Three out of five of Milo's feats of strength involved props. The discus, though obviously athletic, bears no relation to Milo's own athletic event (wrestling); the cord recalls both the taenia athletes tied around their heads (as in the so-called Diadumenos of Polykleitos) and the olive stephanos awarded to Olympic victors; the pomegranate is more difficult to explain, and Pausanias makes no attempt to link it either to athletics in general or to Milo in particular. Unlike the first feat of the statue, feats two through five-the pomegranate, the discus, the cord, and the right hand-find no close parallels in the mythographic stories about other athletic victors of the sixth and fifth centuries that abound in sources of much later periods. The account of Milo of Croton in Philostratos' life of Apollonios of Tyana (VA 4.28) may explain why. Here four of Milo's five feats of strength mentioned by Pausanias - the pomegranate, the discus, the cord, and the right hand-are presented as iconographic attributes of a bronze portrait statue of Milo at Olympia, in all likelihood the same statue seen by Pausanias:

And he also explained the Milo in bronze and the story of its pose. For Milo seems to stand on a discus with both feet together, and he holds a pomegranate in his left hand, while the fingers of his right hand are straight and pressed together. The stories at Olympia and Arkadia concerning this athlete recount that he became inflexible and could not ever be moved from the spot on which he stood, and that the grip of the fingers in grasping the pomegranate shows that they could never be separated from one another if someone struggled with any one of them because the intervals between the extended fingers are very close; and they consider the taenia with which he is bound up to be a symbol of sophrosyne. ${ }^{29}$

Because Pausanias failed to connect the stories of Milo's feats of strength to the iconography of the portrait statue he himself saw at Olympia, J. G. Frazer rejected Philostratos' description of the statue as wholly imaginary, and derivative of Pausanias' earlier written account of Milo's feats of strength. ${ }^{30}$ But Pausanias' lack of authorial intervention in this case is not decisive; at Olympia in particular, he very seldom describes the material, poses, or hand-held attributes of the athletic portraits he includes in his account, usually selecting statues to mention because the athletes they represented were worth remembering. ${ }^{31}$ If Pausanias' informants,

29. Trans. F. C. Conybeare (modified).

30. Frazer 1898: vol. 4, 44.

31. For Pausanias' principles of selection, see Paus. 6.1.2 ("I shall not even record all those [Olympic victors] whose statues have been set up, as I know how many have before now won the crown of wild olive not by strength but by the chance of the lot. Those only will be mentioned who themselves gained some distinction, or whose statues happened to be better made than others") and 10.9.1 ("I will mention those of the anathemata [at Delphi] that seemed to me most worthy of mention. The athletes and competitors in music that the majority of mankind have neglected, are, I think, scarcely worthy of serious attention; and the athletes who have left a reputation behind them I have set forth in my account of Elis"). 
their precise identities as usual disguised behind $\lambda \varepsilon^{\prime} \gamma \varepsilon \tau \alpha \iota$ and $\varphi \alpha \sigma^{\prime}(\nu$, told stories of Milo's legendary feats of strength that agreed with the iconography of the portrait statue in the Altis, there was no need for Pausanias to signal this fact; similarly, we learn of disagreements between the author and his informants (such as the ones mentioned at the beginning of this article) only when Pausanias brings them to his readers' attention.

The conclusion that Milo's feats of the discus, the pomegranate, the cord, and the unmovable right hand, as transmitted by Pausanias, were based upon the iconography of his portrait statue is certainly not new, having been proposed already before Frazer published his commentary on Pausanias. ${ }^{32}$ What is remarkable is that Philostratos, like Herodotus confronted with the twenty handless servant girls of Mycerinus at Saïs, attempts to unmask the stories told about Milo's portrait statue at Olympia as Monument-Novellen, biographical accounts of Milo based entirely upon a misreading of his portrait's iconography:

Apollonius, while admitting that this account was wisely conceived, said that the truth was even wiser. "In order that you may know," he said, "the meaning of the statue of Milo, the people of Croton made this athlete a priest of Hera. As to the meaning of the mitra [headband], I need not explain it further than by reminding you that the man was a priest. The pomegranate is the only fruit grown in honor of Hera; and the discus beneath his feet means that the priest is standing on a small shield to pray to Hera; and this is also indicated by his right hand. As for the rendering of the fingers and the lack of space between the feet, that you may ascribe to the archaic sculptural technique." 33

The method of iconographic analysis practiced by modern scholars can best be described as a process of reading visual signs (pose, hand-held attributes, and costume) in sculpture and the other arts to unlock the meaning of ancient artistic representations; iconatrophy, as it is defined and exemplified by anthropologists, involves the misreading of signs and the misinterpretation of sculptural iconography over the course of time. In Philostratos' account, Apollonios of Tyana rejects the stories current about Milo's pomegranate, discus, cord, and right hand as iconatrophic and offers his own reading of the same iconographic signs as a corrective: he reidentifies the cord as a priestly mitra and the discus as a shield, connecting these, the pomegranate, and the (praying) gesture of the right hand with Milo's service as a priest of Hera Lakinia in his native city of Croton. At the same time, Apollonios declines to read any significance (beyond indicating the statue's great age) into the statue's stance with both feet together, an iconographic

32. The dependence of Pausanias' account upon the statue at Olympia may have been suggested first by Scherer 1885: 25.

33. Philostratos VA 4.28, trans. F. C. Conybeare (modified). 
feature contributing to the local story that Milo stood so firmly on his discus that no one could move him. ${ }^{34}$

Modern commentators have not hesitated to dismiss Apollonios' interpretation of the iconography of Milo's portrait statue as even more implausible (and, in the terms advocated by this article, no less iconatrophic) than the local traditions it sought to correct. In the absence of the statue to which both Pausanias and Philostratos refer, how do we enforce a valid distinction between iconographic reading and iconatrophic misreading? An essential first step toward establishing some sense of the process by which the portrait statue of Milo of Croton at Olympia could have been misinterpreted over time is to determine what the statue looked like. Others, including Elena Ghisellini, who has produced the most thorough iconographic reconstruction to date, have already pointed out that Milo's portrait statue sounds very much like an Archaic kouros with both forearms extended. ${ }^{35}$ Though Milo's first victory in the men's wrestling at Olympia has been dated to $532 \mathrm{BCE}(\mathrm{Ol} .62)$ and his last to 516, there is no guarantee that his portrait was dedicated at Olympia on his own initiative and during his own lifetime: several of the known portrait statues of victors of the period before 500 BCE at Olympia were in fact posthumous retrospective monuments of the fifth century. ${ }^{36}$ Since the sculptor Dameas of Croton is otherwise unknown and no inscribed base from Olympia has been convincingly associated with Milo's portrait, it is also possible to reconstruct a pre-Polykleitan, early Classical figure of ca. 480-450 BCE with both feet flat and close enough together to fit the specification in Philostratos that there was no distance between the feet. ${ }^{37}$

According to Philostratos' description, Milo was depicted standing on a discus, which Apollonios of Tyana reinterpreted as a shield associated with the cult of Hera at Croton; in the third feat of strength in Pausanias' account, Milo stood on an oiled discus from which he could not be dislodged. The discus might

34. For Apollonios' role as an interpreter of the sacred (ta hiera) in Philostratos, see Bowie 1978: 1688-90 and Elsner 1997: 25-28.

35. Reisch 1890: 40-41; Ebert 1972: 183-84; Hurwit 1985: 15-16; Ghisellini 1988: 4449; Gross 1988: 367; and Lattimore 1988: 255. Cf. Bötticher (1856), who accepted Apollonios' explanation of Milo's portrait statue.

36. See Amandry 1957: especially 63-64 and 68-69.

37. Pausanias (10.9.8) also mentions another sculptor named Dameas of Kleitor who made three statues for the Lysander statue group of 405 BCE at Delphi. A heavily damaged round base with the remains of an Archaic inscription (Dittenberger and Purgold 1896: no. 264) has been suggested (notably by Frazer) as a possible base for Milo's statue because the inscription reads ] Ho $_{\alpha} \nu \varepsilon \varepsilon \theta \varepsilon \varepsilon \nu$, and Milo's patronymic was Diotimou. If the drawing of the base published by Loewy (1885: no. 414 ) is accurate, a second inscription on the top of the base cannot be restored as the signature of Dameas and may be a later addition; the corner of a deep cutting preserved along the break at the back of the base, if it was in fact for the attachment of a statue, does not leave room on the base for a life-size or near life-size figure. The base is not certainly for an athletic dedication, and might instead have supported a small bronze statue of Zeus. An elegiac couplet on a statue of Milo included in the Planudean Anthology (Anth. Plan. 16.24) seems to date to the Hellenistic period, and may be a literary exercise rather than a statue base inscription (Ebert 1972: 182-85, no. 61 and Ghisellini 1988: 45). 
in reality have been a round bronze plinth used to attach Milo's statue to its stone base by the so-called Samian technique, a form of attachment used for large-scale bronze sculpture in the late Archaic and early Classical periods which became obsolete at some point in the fifth century; if so, the use of a bronze plinth and the plinth's round (as opposed to rectangular) shape might have appeared unusual and in need of explanation to observers of later periods. ${ }^{38}$ In the near total absence of preserved large-scale Greek bronze originals of the Archaic and early Classical periods, the chief iconographic sources available for comparison with Milo's portrait statue are contemporary bronze statuettes, and among these can be found some examples holding a pomegranate in an outstretched hand. Other examples make a hand gesture that agrees well with the descriptions of both Pausanias and Philostratos; a late Archaic statuette in the Metropolitan Museum in New York (the so-called Baker kouros, Figure 1) extends his left hand with fingers straight and holds an unidentified object in his right. ${ }^{39}$ Even so, both the pomegranate in Milo's left hand and the gesture of his right hand continue to resist definitive modern "iconographic" interpretations. Was the pomegranate actually a round aryballos, more easily explicable in an athletic context? The fact that Pausanias (6.9.1) claims to have seen a pomegranate in the hand of another victor portrait at Olympia, that of the mid-fifth-century boy wrestler Theognetos of Aegina, suggests rather that Pausanias and his sources identified Milo's handheld attribute correctly, even if they ultimately misinterpreted its significance. ${ }^{40}$ Was Apollonios of Tyana (Philostratos) correct to recognize the gesture of Milo's right hand as one of prayer, an interpretation perhaps supported by Pausanias' references to other statues of praying athletes in the Altis? Since no praying

38. For examples of the Samian technique from the Athenian Acropolis, see Kissas 2000: nos. B7 and B14. The only round example I know of is the cutting (for the base of a bronze vessel?) on top of the late Archaic Potter Relief (Raubitschek 1991: 212-19). The Berlin Foundry Cup (ca. 490-480) illustrates an over-life-size bronze statue of a warrior on a rectangular, Samian technique plinth (Keesling 2003: 79-81). Another possible explanation for the bronze discus is a round bronze plate attached to the top of a stone base, but this technique may not have been introduced until the fourth century: for examples, see Mattusch 1996: 176 and 224-31, no. 23 (Washington Dionysos with hexagonal bronze plate, first century BCE or CE) and Mattusch 2002 (Vele Orjule Apoxyomenos with rectangular bronze plate, fourth century BCE or later). An unusual inscribed base of ca. 500-490 from Olympia discussed by L. H. Jeffery (1949: 26-30; Jeffery 1990: 196, no. 49; and Haynes 1992: 19 n. 56) could conceivably have supported a bronze statue on a round bronze plinth rather than a hollow bronze statue made by the sphyrelaton technique. Pausanias (5.25.12) refers to a ten cubit tall bronze statue of Herakles by the late Archaic/early Classical sculptor Onatas of Aegina with a bronze base (bathron) (Haynes 1992: 102-103).

39. Late Archaic nude male statuette with pomegranate in right hand: Richter 1970: 142-43, no. 175, figs. 515-17 and Ghisellini 1988: 46 and fig. 3 (Berlin, from Naxos, inscribed with dedication to Apollo the far-darter). Richter, following Neugebauer (1931: 90-93, no. 192) identified the object as an aryballos, but the figure's long hair and the hole in the left hand (for a bow or laurel branch?) suggest Apollo. Baker kouros: Richter 1970: 135-36, no. 158, figs. 470-73, and Kozloff and Mitten 1988: 66-69, no. 5. Statuette with right hand making the same gesture: Ghisellini 1988: 47 and fig. 4 (Vienna Kunsthistorisches Museum).

40. Pausanias' remark is revealing: "Why Theognetos carries the cone of a cultivated pine and a pomegranate I could not conjecture; perhaps some of the Aiginetans may have a local story about it." 
athletes survive, we cannot be sure what the gesture interpreted by Pausanias as one of prayer looked like; the standard prayer gesture depicted in marble votive reliefs of the Classical period is not identical with either the gesture of Milo's statue or with that of bronze statuettes. ${ }^{41}$

Pausanias repeats the story that Milo was able to break a cord tied around his head by holding his breath and expanding his veins; Philostratos' sources interpreted the cord as a taenia (fillet) symbolizing Milo's sophrosyne; and Apollonios of Tyana reinterpreted the cord as a priestly mitra. These are surely the most puzzling iconatrophic "readings" of all. If Milo was indeed depicted at Olympia with a cord tied around his head, why was it not recognized in the second century CE as the taenia worn by victorious athletes? Pausanias saw at least one athletic victor statue in the pose of a diadumenos elsewhere in the Altis. ${ }^{42}$ The simplest answer is that the process by which the statue of Milo at Olympia was interpreted by observers of the Roman imperial period was not analogous to modern iconographic analysis. Pausanias' and Philostratos' local sources had no encyclopedic iconographic resources to which they could refer to explain poses, attributes, or sculptural techniques; even the late Archaic and early Classical bronze statuettes used as comparanda for Milo's lost statue were not a common type of votive dedication at Olympia and thus would not have been available to an observer of the second century CE. ${ }^{43}$ Pausanias' account of Olympic victors and their portrait statues in the Altis is heavily biased toward victors of the Archaic and Classical periods; at the same time, Pausanias' text reveals that the portraits of the earliest victors as he found them were often in poor condition, with faded or lost inscriptions. In some cases, the original identities of surviving statues had been forgotten, and in other cases portraits whose inscriptions Pausanias was still able to read were popularly misidentified. ${ }^{44}$

41. For praying athletes, see Hyde 1921: 130-33; Renate Thomas 1981: 95-99; and Serwint 1987: 128-31. Not only athletes were shown praying: Pausanias (5.25.5) says that a group of bronze paides at Olympia dedicated by Akragas and made by Kalamis showed the boys stretching out their right hands in an attitude of prayer. For the prayer gesture in votive reliefs (right hand raised with palm flat), see van Straten 1995: figs. 65, 66, 77, 82, 89, and 90. The upraised arms of the bronze statue called the "Praying Boy" in Berlin are probably seventeenth-century restorations; before the nineteenth century, the figure was at different times identified as Ganymede, Antinoös, and Apollo (Hackländer 1997).

42. For the taenia as an attribute of victorious athletes and their portrait statues, see Hyde 1921: 148-50 and Serwint 1987: 107-109. For diadumenoi in Greek sculpture, see Hyde 1921: 150-55; Renate Thomas 1981: 91-93; Serwint 1987: 375-79; and Ridgway 1995: 187-88 (Polykleitos).

43. Athletic statuettes rare at Olympia: Sinn 1989. Late Archaic and early Classical bronze athlete statuettes from the Athenian Acropolis: Niemeyer 1964: 26-27 and pl. 21 (runner, jumper, or wrestler) and 27-28 and pl. 22 (discus thrower).

44. Faded inscriptions or no inscription: "The other statue, which has no inscription, they recall is one of Aristotle from Stageira in Thrace, and that either a student or a soldier dedicated it" (Paus. 6.4.8); "the portrait statue of Eutelidas [of Sparta] is old (archaia), and the letters on the base are faded by time" (Paus. 6.15.8). Forgotten identities: "It is necessary to mention in my account the boy binding his head with a taenia because of Pheidias and his skill (sophia) for making statues, but we do not know whose portrait the statue is that Pheidias made" (Paus. 6.4.5). Misidentification: 
The context in which the portrait statue of Milo at Olympia continued to be meaningful in Pausanias' time was biographical, not iconographic. Despite the fact that no inscribed base survives and the precise date of Milo's statue cannot be determined, the inscriptions on the extant bases for athletic victor portraits of the sixth and fifth centuries BCE show clearly that the stories of Milo's feats of strength current in the Roman imperial period did not derive from statue base inscriptions: these were of limited value as biographical sources, seldom if ever supplying more than the victor's name, patronymic, event, home city, a list of his victories, and the name of the sculptor. ${ }^{45}$ The oral biographical traditions that accrued over time to several early Olympic victors-Milo of Croton, Theogenes of Thasos, and Euthymos of Locri-not only attributed to them extraordinary feats of strength and appetite, but also assimilated them to Herakles and other heroes. ${ }^{46}$ In the case of Milo, the iconography of his portrait statue may have contributed to the formation of these traditions and continued to reinforce them;

\footnotetext{
"There is in Olympia a stele recording the victories of Chionis the Lakedaimonian. Those who hold the opinion that Chionis dedicated the stele himself, and not the koinon of the Lakedaimonians, are stupid.... And those who say that the statue standing alongside the stele is a portrait of Chionis are even more stupid, because it is the work of the Athenian Myron" (Paus. 6.13.2). Pausanias (8.40.1) saw a portrait statue of Arrhachion, three-time Olympic victor in the pankration in the second quarter of the sixth century BCE, in the agora of Phigaleia in Arcadia, and noted that its inscription was no longer visible. The statue Pausanias saw may in fact be a marble kouros from Phigaleia now in the Olympia Museum (Richter 1970: 77 and 67, no. 41 and figs. 144-46), but the remains of the statue suggest that it was really an Apollo holding attributes in both hands. In this case, an Archaic Apollo standing in the agora of Phigaleia was probably misinterpreted as a portrait of Arrhachion.

45. For metrical examples from Olympia, see Ebert 1972: nos. 5 (Pantares of Gela), 14 (Tellon of Oresthasion in Arkadia), 16 (Euthymos of Lokri), 20 (Ergoteles of Himera), and 21 (Kyniskos of Mantinea). Virgilio (1972) argues that even Herodotus in the fifth century relied primarily upon oral sources rather than inscriptions as a source of information about athletes. Herodotus mentions Milo only once (3.137.5), when the Greek physician Demokedes of Croton tells Darius that he is engaged to Milo's daughter.

46. See Fontenrose 1968 and Bohringer 1979. Currie (2002) has recently argued that Euthymos received hero cult within his own lifetime; even so, many of the stories about Euthymos and other early Greek athletes found in much later sources are literary topoi unlikely to reflect accurately the biographies of individual athletes. For a list of heroized Archaic and fifth-century Greeks including athletes, see Connolly 1998: 21. Theogenes of Thasos, a periodonikes of the first quarter of the fifth century, was honored by portrait statues at Olympia, Delphi, and the agora of Thasos and eventually worshipped as a god (Paus. 6.11.2-9 and Dio Chrys. Or. 31.95-97). Though his portrait at Olympia was signed by the contemporary sculptor Glaukias of Aegina, the list of victories inscribed on the base (Dittenberger and Purgold 1896: no. 153) appears to date later (Amandry 1957: 65). The inscriptions on the bases of his portrait statues at Delphi (Ebert 1972: 118-26, no. $37=$ Hansen 1989: no. 844) and on Thasos (Grandjean and Salviat 2000: 73-76) both date to the first half of the fourth century. The earliest evidence for Theogenes' cult, an inscribed thesauros from Thasos, dates to the second century BCE, and it is clear that post fifth-century oral traditions contributed to the stories about Theogenes: literary sources of the Roman imperial period are unanimous in calling him Theagenes son of Timosthenes rather than Theogenes son of Timoxenos, the form of his name that appears in all earlier inscriptions (Pouilloux 1994). The early Hellenistic epigram by Poseidippos of Pella on one of Theogenes' portrait statues (Athen. 10.412.d-e) may be an example of iconatrophy: the epigram explains the pose of the statue with one hand outstretched as Theogenes asking for more meat, but the hand may originally have held a phiale or some other lost attribute (as suggested by Chamoux 1979: 152-53).
} 
the phenomenon of iconatrophy in oral traditions identified by anthropologists clarifies one process by which this may have occurred. ${ }^{47}$ In the Hellenistic and Roman periods, the poses and attributes of portrait statues were to some extent biographical, and later developments in Greek portraiture would only have encouraged the reinterpretation of surviving Archaic and Classical portrait statues as proofs supporting primarily oral biographical traditions. ${ }^{48}$ This process was by no means limited to portraits of athletes. Plutarch (Pericles 3.2-4) interpreted the "schinocephaly" of portraits of Perikles as illustrating a characteristic deformity of Perikles' head referred to by Aristophanes, but the elongated heads seen in Roman marble copies of Perikles' portrait can be explained as the survival of a feature used to facilitate the attachment of the helmet in the lost Classical bronze original. ${ }^{49}$ Given the 550- or 600-year gap between the dedication of Milo's portrait statue and Pausanias' visit to Olympia, it is naïve to suppose that the original meanings of statues and other monuments continued to be transmitted accurately. Even famous statues that continued to be viewed within their original contexts in Greek sanctuaries were potentially unstable in their meanings and capable of reinterpretation.

\section{LEAINA ON THE ATHENIAN ACROPOLIS}

According to Pausanias (1.23.1-2), the Athenians of his own time explained the bronze statue of a lioness standing at the entrance to the Athenian Acropolis, next to the Aphrodite dedicated by Kallias and made by Kalamis, as a memorial to Leaina ("lioness"), a mistress of the tyrant-slayer Aristogeiton tortured and killed by the tyrant Hippias after the assassination of Hipparchos in 514 BCE. In Gorham P. Stevens' imaginative reconstruction of the Acropolis as Pausanias saw it (Figure 2), the lioness stands on a pillar to the left of a crouching nude Aphrodite just inside the eastern colonnade of the Propylaia of Mnesikles. Pausanias explicitly recognizes the story of Leaina as an oral tradition current in his own time:

And yet Peisistratos and his son Hippias were more humane than Periander, wiser too in war and in matters of state, until, on account of the

47. Cf. Serwint 1987: 103-104: "Obviously, the iconography of the victor statue was adopted from the remarkable feats of the athlete. Complex icongraphic programs were not unknown in the sixth century, and it is likely that the meaning behind Theognetus' statue [Paus. 6.9.1] was equally complex." The phenomenon of using portrait statues as biographical sources proposed here is analogous to the use of their poetry as a source for the biographies of early Greek poets described by Lefkowitz 1978.

48. An example of biographical accuracy in later portrait statues: the early Hellenistic portrait of Menander in the theater of Dionysos in Athens (reconstructed by Fittschen 1991) depicted him without a beard.

49. As argued by Cohen 1991b: 500: "Earlier discussions of Perikles' portrait have gone astray by interpreting in physiognomic or stylistic terms a technological characteristic of helmeted Greek bronze statues from the fifth century BCE, which, nearly two millenia ago, may also have deceived Plutarch.” But cf. the reservations expressed by Krumeich 1997: 120-21. 
death of Hipparchos, Hippias vented his passion against others, including a woman named Leaina. What I am about to say has never before been committed to writing, but is otherwise believed by the majority of Athenians. When Hipparchos died, Hippias tortured Leaina to death, because he knew she was mistress of Aristogeiton, and therefore could not possibly, he thought, be ignorant of the plot. In return, when the tyranny of the Peisistratidai ended, the Athenians put up a bronze lioness as a memorial (mnèma) of the woman, and beside it is an agalma of Aphrodite, which they say is the dedication of Kallias and the work of Kalamis. ${ }^{50}$

Contrary to Pausanias' claim that the story of Leaina had never before been written down, Pliny (HN 34.72 and 7.87) had already included a version of the same story in his book on bronze sculpture and attributed the statue to a sculptor named Amphikrates. Both Pliny and Plutarch (De garr. 505d-e) add that the lioness statue lacked a tongue because Leaina had refused to name her co-conspirators. Pliny attributed the use of the figure of a lioness rather than a portrait statue to commemorate Leaina to the Athenians' unwillingness to award a normal honorific portrait to a mere prostitute. ${ }^{51}$ Though the story of Leaina enjoyed its greatest popularity in the works of second sophistic authors, it is possible that Cicero in the late Republic referred to both the statue on the Acropolis and the story of the prostitute Leaina in his lost work De gloria. ${ }^{52}$ Neither the story nor the statue is known to have been mentioned in any earlier literary work, and no statue or inscribed base has been found on the Acropolis that can be associated with the bronze lioness Pausanias saw.

Commentators of the late nineteenth and the earlier twentieth centuries were practically unanimous in dismissing the Leaina story as a Monument-Novelle derived entirely from the statue of a lioness. ${ }^{53}$ Oddly enough, the tendency in more recent scholarship has been either to allow Pausanias' explanation of the lioness on the Acropolis to stand without further comment or, at the very least, to accept the statue as an authentic Archaic votive dedication, a rare survivor

50. Trans. W. H. S. Jones (modified).

51. Pliny calls Leaina the mistress of Harmodios, not Aristogeiton. Polyaenus (Strateg. 8.45) follows Pliny both in mentioning that the statue lacked a tongue and in claiming that the Athenians denied Leaina a true "portrait." Athenaeus (13.596f) mentions a mistress of Harmodios named Leaina but not the lioness statue on the Acropolis.

52. See Philargyrius on Verg. Ecl. 2.63: Cicero de gloria libro...sic ait: Statuerunt simulacrum Leaenae (Thilo and Hagen 1887: 3.2.45).

53. Frazer (1898: vol. 2, 273-74) summarizes earlier scholarship; Jacoby (1949: 166-68 and 344 n. 92) identified the story as an aition for the statue and attributed it to "Hellenistic periegetai." Eugenie Sellers [Strong], in her commentary on Pliny (Jex-Blake and Sellers 1896: 59), called the Leaina story "an obvious invention" for three reasons: the bronze lioness stood on the Acropolis, not near the portrait statues of Harmodios and Aristogeiton in the Agora; Herodotus and Thucydides do not mention Leaina; and the lioness statue's missing tongue could be enough to explain the origins of the story. 
of the Persian sack of 480 and the rebuilding of the sanctuary that followed. ${ }^{54} \mathrm{I}$ would like to revive the suggestion that the story of the prostitute Leaina in its entirety can best be explained as a Monument-Novelle inspired by the fact that a bronze statue of a lioness stood near a famous statue of Aphrodite in the Propylaia of the Athenian Acropolis in the Roman period. The most clearly iconatrophic detail of the story is the explanation of the statue's missing tongue that we find in Pliny, Plutarch, and Polyaenus: this sounds like the result of damage to the statue over time, and there is further evidence for damaged statues standing in Greek sanctuaries in the Roman period. ${ }^{55}$ Yet the oral tradition of Leaina in its entirety could also have arisen through a process of iconatrophy in response to two aspects of the Acropolis statue that made little sense to observers: the very fact that a bronze lioness was dedicated on the Acropolis, and the lioness' placement near an image of Aphrodite which itself may have lacked an obvious cultic justification on the Acropolis. The term iconatrophy can be applied to the mistaken reading not only of a statue's iconographic features (such as Milo of Croton's pomegranate and taenia), but also of its location or its grouping with other statues. Even if we as modern observers fail to recover the original significance of the bronze lioness statue, the case can still be made that the story of Leaina as we have it betrays the workings of attitudes that postdate the events of the late sixth century BCE supposedly commemorated by the statue.

Explaining what the Leaina monument on the Acropolis really was proves to be extremely difficult, and the lack of extant parallels for a large-scale statue of a bronze lioness available to modern Classical archaeologists only reinforces the supposition that the monument was perceived in antiquity as unusual. Neither Pausanias nor any other source describes the statue's appearance beyond its missing tongue; nor does Pausanias signal any discrepancy between the late Archaic date for the statue implied by the Leaina story and the statue's sculptural style,

54. Lioness statue taken literally as a monument to Leaina: Fuchs 1995; Brouskari 1997: 230; and Künstlerlexikon der Antike I (A-K), s.v. Amphikrates (E. Paul and W. Müller). Statue accepted as Archaic: Boardman 1986. Cf. Hurwit 1999: 129 ("the story sounds apocryphal") and 141 (Pausanias saw a bronze lioness "that the Persians evidently missed or ignored" in the 480 BCE sack of the Acropolis). Forrest (1995) suggested that the line "I will not stand like a lioness on a cheese-grater" in the women's oath in Aristophanes' Lysistrata might be an allusion to Leaina and her monument on the Acropolis (I owe this reference to Ben Millis).

55. It is difficult to find sculpted felines with tongues detached rather than adhering to the lower teeth. One example is a small bronze chimaira of the early fifth century from Orchomenos (LIMC III.1, s.v. Chimaira, no. 97 [A. Jacquemin]); a fourth-century marble lion in the Nelson-Atkins Museum of Art in Kansas City appears to have a detached tongue (Ward and Fidler 1993: 118). I thank B. Ridgway for alerting me to this problem. Favorinus ([Dio Chrys.] Or. 37.40) refers to a portrait statue of Alcibiades not only reinscribed as a portrait of a Roman, but also missing both hands; Pausanias mentions a fifth-century bronze statue of a horse with its tail cut off at Olympia (5.27.3) and a small wooden herm of Aphrodite on Delos with its right hand damaged by time (9.40.3). A hilarious example of misinterpretation as a result of damage occurs in Lucian's Demonax (53): Demonax, seeing a bronze statue with its hand cut off standing near the Stoa Poikile in the Athenian Agora, interprets it as a portrait of Kynegeiros, the brother of Aeschylus who had his hand cut off at the battle of Marathon (as depicted in Polygnotus' painting inside the stoa). 
as he does in some other cases. ${ }^{56}$ Stone lions were a relatively common-though poorly understood - type of freestanding votive dedication in Greek sanctuaries in the Archaic period. ${ }^{57}$ It is inherently unlikely, though, that any large-scale bronze statue of a lioness (or any other subject for that matter) survived the Persian sack of the Acropolis in 480 BCE intact. ${ }^{58}$ Two major considerations make a date in the Classical period between 480 and about 350 BCE plausible for the Acropolis lioness. Pausanias' chronological bias toward mentioning early monuments on the Athenian Acropolis can be controlled to some extent by comparing his account with extant inscribed statue bases, and the bases show a very sharp decline in the dedication of any statues other than honorific portraits after ca. 350 BCE. Second, the great majority of the animal statues known at Delphi through a combination of literary references and inscribed bases date to the sixth and fifth centuries. ${ }^{59}$ This is not at all surprising given that this was the heyday of votive dedications in Greek sanctuaries: that is, of monuments of all types (including divine images, animal statues, and portraits) inscribed with the names of their dedicators and the recipient deity, as opposed to honorific portrait statues inscribed with the names of their subjects. Even a Classical bronze statue of a lioness might have appeared sufficiently old to an observer of the Roman imperial period to justify a retrospective association with the Peisistratid tyranny. ${ }^{60}$

Neither Pausanias nor any of the other sources mentioning the lioness statue on the Acropolis refers to an inscription. The only information likely to have come from reading an inscription on the monument is the name of the sculptor Amphikrates, and this sculptor is otherwise unknown. The statue of Aphrodite

56. Cf. Pausanias' comment on a portrait statue of Aeschylus he saw in the theater of Dionysos in Athens (1.21.2): "I think the portrait of Aeschylus is much later than his death and than the painting which shows the action at Marathon [in the Stoa Poikile]." The statue Pausanias saw might have been a Hadrianic replacement $\left(\mathrm{IG} \mathrm{II}^{2} 4265\right)$ of the retrospective portrait of the fourth century $\mathrm{BCE}$ ([Plut.] X oratt. 841-42).

57. For Archaic marble lions from the Athenian Acropolis, see Schrader 1939: nos. 382-84 (these might in fact be acroteria rather than votives); cf. Lazzarini 1976: no. 690 (inscribed marble lion from Miletus) and the golden lion dedicated by Croesus at Delphi (Hdt. 1.50). A bronze lion standing over a fountain house in Athens was called the krenophylax (Pollux 8.113; I owe this reference to Judith Binder). The heavily restored colossal bronze lion-griffin now standing atop a column in the Piazza San Marco in Venice is probably an east Greek original of the later fourth or early third century BCE; like the Acropolis lioness, it too lacks a tongue (Scarfî 1990: 90-113).

58. The only remains of Archaic large-scale, hollow cast bronze statues found in the Acropolis excavations are two male heads (Ridder 1896: nos. 767 and 768 and Mattusch 1988: 91-95 and figs. 5.2 and 5.5) and a drapery fragment probably belonging to a half-life-size statue of Athena (Ridder 1896: no. 664).

59. Exceptions: the bronze lion dedicated by the Elateians (Phocis) at Delphi in thanksgiving for withstanding the siege of Cassander (Paus. 10.18.6 and Jacquemin 1999: no. 280, beginning of the third century BCE) and the bronze bison head dedicated at Delphi by king Dropion of the Paionians (Paus. 10.13.1 and Jacquemin 1999: no. 366, second quarter of the third century).

60. Pausanias and other second sophistic authors certainly applied the term archaios not only to Archaic sculpture (ca. 700-480 BCE), but also to works of the early Classical period (see most recently Arafat 1996: 45-79, especially 58-63); in some cases, even late Classical statues were perceived to be archaios (Paus. 1.37.5, cited by Kreilinger 1997: 477). 
made by Kalamis has been identified by Angelos Delivorrias as a lost original copied by the Roman "Aphrodite-Olympias" type, but this identification has been disputed by Ridgway and others. ${ }^{61}$ The work of the sculptor Kalamis is usually dated between ca. 470 and 440 BCE. The Aphrodite on the Acropolis, even if it dates near the end of Kalamis' attested career, still apparently predates the Propylaia in which Pausanias saw it. The Aphrodite of Kalamis would not be the only example of a votive monument moved after the construction of the Propylaia of Mnesikles, completed in 432 BCE: Herodotus (5.77.4) refers to a bronze quadriga group commemorating the Athenian victory over the Boiotians and Chalkidians in 507/6 standing at the entrance to the Acropolis, but by the time of Pausanias (1.28.2) the same monument had been moved to the west end of the Archaic Old Athena temple foundations, near the colossal bronze Athena by Pheidias (where it appears in Stevens' reconstruction). ${ }^{62}$ What this means is that if the bronze lioness statue dated before the completion of the Propylaia in 432 BCE, its placement near the Aphrodite of Kalamis cannot be its original location. One can also hypothesize that the Aphrodite was placed inside the Propylaia as a result of post-fifth-century rearrangements rather than any cultic necessity predating the construction of the building. ${ }^{63}$ At least one other "visiting god" was dedicated in the sanctuary of Athena on the Acropolis by private individuals in the fifth century for reasons that can be characterized as personal rather than cultic: this is the image of Artemis Leukophryene set up by Themistokles' sons after his death in exile in Magnesia on the Meander (Paus. 1.26.4). The precise location of both the lioness and Kalamis' Aphrodite within the Propylaia of Mnesikles remains unknown. ${ }^{64}$

61. Inscribed base: Raubitschek 1949: 152-53, no. 136 and IG I ${ }^{3}$ 876: "Kallias dedicated. Kalamis made it." The base was found in the Agora, and Raubitschek suggested that the statue was given a new base when it was moved into the Propylaia. Statue identified with Aphrodite-Olympias type: Delivorrias 1978 (ca. 450-440 BCE); cf. Ridgway 2002: 195-97. The Kallias who dedicated the statue is usually assumed to be Kallias son of Hipponikos, whose embassy to the Persians in 450 led to the so-called Peace of Kallias, and who dedicated another statue on the Acropolis with his patronymic (Raubitschek 1949: 114-16, no. 111). But Kallias was a common name in fifth-century Athens, and the statue may eventually have been moved to its prominent position because it was thought to be a dedication by the famous Kallias. This same Kallias was represented by a portrait statue in the Agora near Kephisodotos' Peace and Wealth (second quarter of the fourth century BCE), almost certainly a retrospective honorific portrait of the fourth century BCE or later (Paus. 1.8.2).

62. The original version of the monument ( $\mathrm{IG} \mathrm{I}^{3}$ 501A), dedicated soon after 507/6, was apparently destroyed in the Persian sack of $480 \mathrm{BCE}$ and replaced by the version seen by Herodotus in the 430s BCE (IG I $\mathrm{I}^{3}$ 501B).

63. Aphrodite and Eros had a small sanctuary on the north slope of the Acropolis (Travlos 1971: 228-32), and the sanctuary of Aphrodite Pandemos may have been located on the south slope not far from the Athena Nike bastion. Pirenne-Delforge (1994: 26-28 and 32-34) suggests that the Aphrodite of Kalamis was originally dedicated in the sanctuary of Aphrodite Pandemos.

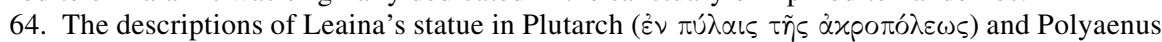
$(\dot{\varepsilon} \nu \tau \tilde{\omega} \pi \rho \circ \tau \nu \lambda \alpha i \omega)$ clearly place it within the building. Stevens' reconstruction places the Aphrodite in a cutting in the pavement just inside the eastern colonnade (Stevens 1936: 446-58 and fig. 3, F), one of two such cuttings located on opposite sides of the central walkway, both confirmed to be ancient by Tasos Tanoulas (Tanoulas 1997: 164 and drawing 9). There is no such cutting where 
The Leaina story succeeds in making sense of the grouping of a lioness statue near a statue of Aphrodite, but there is no way to determine whether that grouping was original. Additional factors may have contributed to the story's formation. In the Hellenistic period, the mistress of Demetrios Poliorketes was a Corinthian prostitute named Leaina, and another famous prostitute named Laïs (believed by Greeks to be the Phoenician word for "lioness") was supposedly commemorated with a monumental tomb on the road to Corinth near a temple of Aphrodite Melainis (Paus. 2.2.4). It seems clear that some form of "lioness" was a common name for Greek prostitutes because it alludes to a sexual position. ${ }^{65}$ Laïs' tomb at Corinth was decorated with a statue of a lioness; this is an example of a "canting device," in which an honorand named after an animal is commemorated by a punning representation of the same animal, a form of Greek monument that appears to go back to the fifth century when a marble lion was set up over the tomb of Leonidas at Thermopylae (Hdt. 7.225.2). Interpreting the bronze lioness statue on the Acropolis as a monument to a woman named Leaina clearly envisions the same sort of device. Yet, with the exception of an Athenian state decree of the fourth century BCE, all other known examples of animals used as canting devices belong to funerary monuments rather than sanctuary dedications, and the great majority date to the Hellenistic period, when the same trope became common in literary epigrams. ${ }^{66}$

The desire to identify the lioness on the Acropolis as a "portrait" of Leaina would also have been reinforced by the common use of marble lions as funerary monuments in Athens and Attica in the late Classical and early Hellenistic periods, until the use of sculpture to decorate tombs was curtailed by the sumptuary law of Demetrios of Phaleron in the last quarter of the fourth century BCE (Cicero De. Leg. 2.66) ${ }^{67}$ By claiming that the Athenians refused the prostitute Leaina a true portrait, Pliny relates the Leaina monument to the normative Athenian practice of honoring

Stevens placed the bronze lioness. It has long been suggested that three of the other statues mentioned by Pausanias in the Propylaia and its vicinity-the Hermes Propylaios of Alkamenes, the Hekate Epipyrgidia, and the Charites by Socrates, son of Sophroniskos-stood in the niches where the north and south wings of the Propylaia join the main building. Each of these statues appears to have been Archaistic in style, and all three may represent cults that predate the construction of the Propylaia (Stevens 1936: 446-47; Linfert 1978; and Palagia 1990: 353-55).

65. For Leaina and Laïs, see Athen. 6.253a-b, 13.577d, and 13.596f, and Gow's (1965: 93) note on Machon frag. 12. Ogden (1999: 247-52 and 260-62) points out that thematically appropriate names, including Leaina, recur frequently for ancient Greek prostitutes.

66. See Ritti 1973-1974, especially 643: “Il legame tra l'etera Leaina e la statua arcaica di una leonessa dovette essere, comunque, immaginato in un' età piuttosto tarda, amante delle leggende etiologiche e dei particolari curiosi. L'episodio rispecchia quindi fedelmente la mentalità dell'epoca ellenistico-romana, ma non può in alcun modo risalire alla fine del VI sec. a.C." Athenian decree of 354/3 in honor of Moschos of Naukratis with a relief of a bull: Lawton 1995: 62-63, no. 32. Dog on the gravestone of Diogenes the Cynic: Hansen 1990. Statue of a heifer on the tomb of the Athenian woman Boidion, wife of Chares, who died at Calchedon (339 BCE): Merkelbach and Stauber 2001: no. 9.07.02.

67. Funerary marble lions: Vermeule and von Kersburg 1968 and Vermeule 1972: 49-56. The marble leopardess now placed near the Beulé gate just west of the Propylaia was first seen on the 
generals, statesmen, and other civic benefactors with bronze portrait statues in prominent public places including the Agora and the Acropolis, a practice that began in Athens only in the early fourth century and continued under Roman rule. ${ }^{68}$ The Athenians' supposed denial of a normal honorific portrait to Leaina assumes the existence of honorific portraits; even if the bronze lioness statue on the Acropolis was set up in the fifth century as I am suggesting, this element of its interpretation must be retrospective. Taken together with the post-fifth century tendency to use statues of animals as canting devices, it casts significant doubt upon claims of an authentic connection between the statue on the Acropolis and any real woman named Leaina. Similarly, literary sources of the Second Sophistic show a remarkable tendency to read Archaic and Classical statues of animals in Greek sanctuaries retrospectively as honorific "portraits" of famous animals: two examples are the stories in Pausanias of a bronze bull dedicated by the people of Corcyra at Delphi to represent a bull that miraculously led the Corcyreans to a gigantic tuna catch (Paus. 10.9.3-4), and the bronze wolf dedicated by the Delphians to Apollo commemorating a wolf that led them to a temple robber's hideout on Parnassus (Paus. 10.14.7). Stories of animals as saviors common in the literary sources belong to a type of oral tradition popular in the Roman imperial period, and many such stories appear to have been generated by monuments. ${ }^{69}$ In reality, most votive statues of animals in Greek sanctuaries including Delphi were dedicated either as commemorations of sacrifice or as representations of animals in some way emblematic either of the dedicators or of the recipient deity, and inscribed only with a basic votive formula. ${ }^{70}$ The fact that the bronze lioness on

south coast of Attica, where early nineteenth-century travellers thought it marked the tomb of Leaina (Vermeule 1972: 56).

68. For honorific portraits in Athens, see Lewis and Stroud 1979. Cf. the ancient criticisms of the golden portrait statue of Phryne, prostitute and mistress of the fourth-century sculptor Praxiteles, at Delphi (Plut. De Alex. fort. 336d and De Pyth. or. 401a and Athen. 13.591b).

69. For the literary topos of animals as saviors, see especially Lacroix 1992: 159-63. Pausanias' story of the Delphian wolf resembles Aelian's (NA 7.13) tale of a dog that foiled a robber of the Athenian Asklepieion, and recurs in NA 12: 40: at Delphi they honor a wolf that found sacred gold, at Samos a sheep was dedicated by Mandroboulos because sheep discovered stolen gold, and at Ambracia they honor a lioness because one killed their tyrant Phaÿllos. Plutarch (Them. 10.6) gives the following aition for the monument on Salamis called the "dog's tomb" ( $x$ ù̀ $\sigma \tilde{\eta} \mu \alpha$ ): Xanthippos' dog, after being left behind in Athens, swam alongside its master's trireme to Salamis where it dropped dead on the spot.

70. For the fragmentary inscribed base of the Corcyrean bull at Delphi, see Jacquemin 1999: no. 122 (first half of the fifth century); for the bronze wolf, see Jacquemin 1999: no. 213 (before the mid-fifth century). Animal statues as commemorations of sacrifice or emblematic: Shapiro 1988; Chamoux 1991; and Jacquemin 1999: 178-79, 208-209, and 83: "les anecdotes relatives aux offrandes préfèrent le miraculeux au quotidien"; for Apollo's association with wolves, see Burkert 1994: 54-59. For votive inscriptions on animal statues see, e.g., the bronze cow dedicated by the Eretrians and made by Philesios at Olympia: "Philesios made it. The Eretrians to Zeus" (Eckstein 1969: 50-53 and Jeffery 1990: 88, no. 19, ca. 480?) and one of the four bronze cows from Hermione: "Alexias Lyonos of Hermione dedicated to Demeter Chthonia. Kresilas of Kydonia made it" (Jameson 1953: 149-50, no. 2). 
the Acropolis did not fit easily within these categories only added to the potential for later misunderstanding.

Even if there are compelling reasons not to take Leaina and her monument on the Acropolis at face value, why did the Monument-Novelle associate Leaina with Harmodios and Aristogeiton? In the Hellenistic period, either Alexander himself or one of his successors returned the original Tyrannicides portrait group by Antenor to Athens, and both the original monument and the replacement group by Kritios and Nesiotes continued to be an important locus for civic memory under Roman rule, as evidenced by the portraits of Brutus and Cassius set up alongside them in the Agora in 44 BCE. $^{71}$ There appear to have been few other surviving commemorative monuments in Athens identified with the Peisistratid tyranny from the fourth century BCE onward. Two exceptions are the bronze stele listing the names of Athenian "exiles and traitors" on the Acropolis said to have been made by melting down a portrait statue of the Peisistratid Hipparchos, son of Charmos (Lycurgus 1.117), and the altar and statue of Eros in the Academy dedicated by Charmos (Paus. 1.30.1 and Plut. Solon 1). The story of Leaina effectively linked an unusual old statue on the Acropolis with the Tyrannicides portraits in the Agora, one of the earliest monumental "proofs" of sixth century Athenian history to be found in Athens in the Roman period when the Leaina story was current. ${ }^{72}$

\section{ATHENA HYGIEIA ON THE ATHENIAN ACROPOLIS}

The Athena Hygieia ("Health") of Pyrrhos is a rare example of a votive statue mentioned by literary sources of any period represented by a complete inscribed base discovered in situ and still visible today (as seen in Figure 3). The statue (now lost) and its base stood in front of the southern corner column of the eastern colonnade of Mnesikles' Propylaia on the Acropolis. This column completely blocks our view of the statue in Stevens' reconstruction drawing Figure 2), but its position is clear in both Adolf Michaelis' late nineteenth-century reconstruction drawings (Figure 4) and in a modern photograph. The inscription on the base is unusually large and deeply carved, but at the same time characteristically uninformative about the occasion for the statue's dedication. It reads simply: "The Athenians to Athena Hygieia. Pyrrhos the Athenian made it."73 A story recounted by Plutarch in his life of Perikles (13.7-8) attempted to fill the gap left

71. Honorific portraits of Brutus and Cassius: Dio Cassius 47.20.4; for the prohibition against setting up all but a select few honorific portraits near the Tyrannicides, see Wycherley 1957: nos. 278 and 279 .

72. The bronze portrait statue of the seventh-century BCE would-be tyrant Kylon seen by Pausanias on the Acropolis (1.28.1) is difficult to explain as anything other than a retrospective monument of the fourth century or later; for the problem of retrospective portraits in Athens, see Zanker 1995.

73. Raubitschek 1949: 185-88, no. 166 and IG I I 824 . 
by the dedicatory inscription, linking the dedication of the statue directly with the construction of the Propylaia:

An amazing piece of luck happened in the course of construction [of the Propylaia], which indicated that the goddess was not staying aloof, but helping in the inception and the completion of the work. The most energetic and zealous of the workmen lost his footing and fell from a height, and lay in a sorry state, despaired of by the doctors. Perikles was discouraged but the goddess appeared to him in a dream and prescribed a course of treatment, which Perikles used to quickly and easily heal the man. It was in commemoration of this that he set up the bronze statue of Athena Hygieia on the Acropolis near the altar that, as they say (is $\lambda \hat{\varepsilon}_{\text {rov } \sigma(\nu), \text { was there before. }}{ }^{74}$

Pliny (HN 22.44 and 34.81) identified this workman as a slave of Perikles, the same one represented by the sculptor Styppax of Cyprus' bronze "Splanchnoptes" statue, which depicted a man roasting the entrails of a sacrificial victim; he also attributed Athena's miracle cure to an herb thereafter called "Parthenium," but did not connect this story either with the Propylaia (the slave is said to have been working on a temple on the Acropolis) or with the statue of Athena Hygieia. Thus Plutarch used one version of the story of the workman as an aition to explain the statue of Athena Hygieia, while Pliny used a slightly different version to explain another Acropolis monument, the Splanchnoptes ("Roaster of entrails") by Styppax, and the name of the herb Parthenium.

The inscribed base for the Athena Hygieia, examined on its own merits, provides unusually specific indications concerning the date and appearance of the lost statue. As the inscribed building accounts for the Propylaia of Mnesikles (IG I ${ }^{3} 462-66$ ) confirm, the building was begun in 437/6 BCE and work came to an end at some point in 432 ; the unfinished state of the building has always encouraged the view that construction was halted for good by the outbreak of the Peloponnesian War in the summer of $431 .{ }^{75}$ The Athena Hygieia base was uncovered during the removal of post-Classical constructions from the Propylaia in either 1838 or 1839 , still standing in situ where it had apparently been incorporated into the foundations of a Frankish palace built in the remains of the Propylaia in the fifteenth century. ${ }^{76}$ Michaelis in 1876 recognized that the statue must have been erected after work on the Propylaia had already been abandoned. Most of the stylobate of the eastern colonnade still has its original

74. Trans. B. Perrin (modified).

75. For the construction history of the Propylaia, see most recently Tanoulas 1994, Tanoulas 1997, and Hurwit 1999: 192-97.

76. Tanoulas (1997: 129) dates the rediscovery of the base to 1839 , but it appears already in a drawing of the Propylaia by James Skene dated 12 November 1838 (Tanoulas 1997: fig. 76). The Athena Hygieia statue base and altar "disappear" in views of the Propylaia made between ca. 1403 and this date, and Tanoulas' reconstructions (drawings no. 64 and 65) indicate that the base was built into the foundations of a wall of the palace. 
working surface, the mantle of stone left on each block by the quarry with the intention that, once the blocks had been transported and set in place, the mantle would be carved away; only small rectangles around the columns of the eastern colonnade had been worked down to their final surface at the point when construction was halted. The inscribed base (D in Michaelis' drawing, Figure 4) was placed on top of a round block equal in height to the working surface of the stylobate (marked $\mathrm{C}$ in the same drawing), an indication that this unfinished surface was already considered "final" when the Athena Hygieia base (and presumably the statue with it) was erected. Michaelis' technical observation thus points to a date for the dedication of the statue and its base after 431 BCE. $^{77}$

The inscribed base for the Athena Hygieia preserves dowel holes for the attachment of the statue's feet. These holes make it clear that the statue was overlife-size and that it stood in the Standbein/Spielbein pose popularized earlier in the fifth century by Polykleitos, with the foot of the weight leg (the right) flat and the foot of the free leg (the left) drawn back and touching the top surface of the base only under the ball of the foot. ${ }^{78}$ The top surface of the base is stippled between the two feet where the drapery between the legs touched it. Finally, a preserved spear hole alongside the left foot shows that the Athena Hygieia held a spear upright in her left hand. ${ }^{79}$ Though the sculptor Pyrrhos is otherwise unknown, attempts have been made to reconstruct the appearance of the lost Athena Hygieia using Roman marble Athenas thought to be copies of originals from the second half of the fifth century. It is not important for the purposes of this article to argue the case in great detail, but at least one of the proposed candidates agrees with the evidence of the statue base and exhibits stylistic features that fit a date after ca. 431 BCE. This is the Hope-Farnese Athena type represented by two examples in the Hope (Los Angeles) and Farnese (Naples) collections, an over-life-size Athena with a spear in her left hand, a chiton touching the top surface of the base beneath her feet, and a helmet inspired by the Athena Parthenos of Pheidias, completed in 438 BCE. $^{80}$

77. Michaelis 1876: 285, followed by Loewy 1885: 44-47, no. 53; Wolters 1891: 157-59; and Frazer 1898: vol. 2, 277-82.

78. For the pose, see Arnold 1969: 20-36. Cf. Robertson (1996: 47-48 and 1999: 178 n. 17), who reconstructs something like the striding Athena figure shown on Panathenaic prize vases, a reflection of a hypothetical sixth-century cult statue of Athena Hygieia on the Acropolis.

79. Cf. Bohn (1880: 332) and Wolters (1891: 164-65), who thought that the spear hole was a later door pivot.

80. For the Hope/Farnese Athena type, see Studniczka 1899: 134-35; Waywell 1986: 67-68, no. 1; and LIMC II.1, s.v. Athena-Minerva (F. Canciani) 1085, no. 148. Stevens in his reconstruction drawing of the view through the Propylaia (my Figure 2) inaccurately reconstructed the mid-fifthcentury colossal bronze Athena by Pheidias on the Acropolis as a variant of this type. Cf. Despinis (1971: 146-55), who objects that the Hope/Farnese type is represented by fewer Roman copies found in Greece than other Classical Athena types thought to copy Athenian originals, such as the Athena Medici type identified with Pheidias' Athena Lemnia on the Acropolis (by Harrison 1988). For Roman marble copies of fifth-century Athenas found in Greece, see Karanastassis 1987 (copy of the Hope/Farnese type found on the Acropolis: 382-83 and 426, no. BVI 2, and plate 52). 
The case for dating the Athena Hygieia statue by Pyrrhos in the 420s, immediately after the construction of the Propylaia, rests upon somewhat circumstantial evidence. Both the form and the placement of the inscribed base have always suggested a close relationship between the statue and the Propylaia; indeed the story in Plutarch of the workman's fall makes sense only if the statue continued to be perceived as connected with the building. The round base with decorative base and crown moldings is almost unparalleled in the fifth century on the Acropolis, but this shape may have been chosen to echo the shape of the column behind it. The back of the base was cut away to allow a closer fit up against the corner column of the Propylaia, and the modification caused both feet of the statue to be placed unusually close to the edges of the base; at the same time, the statue was rotated slightly off of the east-west axis of the Propylaia to permit a better view for those entering and exiting the building. ${ }^{81}$ In addition to the base for the statue, an offering table, of which only the marble base survives (F on Michaelis' plan, Figure 4), and an uninscribed marble altar ( $\mathrm{K}$ on the plan) were found still in situ just to east of the statue. Though sacrifices to Athena Hygieia continued to be made on this altar every year at the lesser Panathenaia (IG II $234,1.9$ ), the introduction of the cult of Asklepios and Hygieia to the South slope of the Acropolis in 420/19 BCE (as evidenced by IG II ${ }^{2} 4960$ ) suggests that the construction of a cult complex to "Athena of Health" makes more sense before 420 than at any time afterward ${ }^{82}$

Paul Wolters in 1891 proposed an ingenious alternative to the aition in Plutarch that also explains the close physical association between the Athena Hygieia statue and the Propylaia. He suggested that the Athenians dedicated the statue to Athena as a thank-offering after the end of the great Athenian plague that, according to Thucydides' chronology, first began in the summer of $430 \mathrm{BCE}$ (Thuc. 2.47-54); its second outbreak did not come to a complete end until 426 (Thuc. 3.87.1-3). It is possible to go further than Wolters did and to conclude that there was no cult place of Athena Hygieia on the Acropolis at all until the Athenians dedicated her statue in front of the Propylaia of Mnesikles. ${ }^{83}$ Two pieces

81. The placement of the inscription on the base also coordinates with an "open" view of the statue. The dedicatory text inscribed in the first line begins just beneath the statue's right foot and ends beneath the spear hole (its position is shown by the line running parallel to the edge of the base D in Michaelis' ground plan, my Figure 4). The signature of Pyrrhos beneath the dedication is end-justified, making it easier to read by viewers entering and exiting the Propylaia. It is one of only four examples of end-justification of sculptors' signatures among the Acropolis dedications of the sixth and fifth centuries (the others are IG I ${ }^{3}$ nos. 683, 763, and 895).

82. Replacement of Athena Hygieia cult by Asklepios cult: LIMC V (1990), s.v. Hygieia, 554-55 (Francis Croissant), and Hurwit 1999: 36, 221, and 331, n. 8. On this view, the statue of the personification Hygieia, seen near the Athena Hygieia by Pausanias (1.23.4), makes some sense as a post $420 / 19$ dedication associating a new cult with the older one.

83. All of the following accept the hypothesis of an earlier cult for one or more of the reasons to be discussed here: Michaelis 1876: 293-94; Wolters 1891: 154; Judeich 1931: 82-83 and 242-44; Aleshire 1989: 11-12; Shapiro 1993: 125-31; Ridgway 1992: 137-38; Brouskari 1997: 232-33; Hurwit 1999: 199; and Robertson 1999: 177-79. Cf. Linfert 1978: 32, who suggests that the Propylaia of Mnesikles encroached upon an earlier cult precinct of Athena Hygieia. 
of archaeological evidence have been cited in support of an earlier cult. The first, introduced by Wolters himself, is a small fragment of Athenian red-figure pottery of ca. 470 BCE found in the Acropolis excavations of the 1880s; a largely preserved dedicatory text inscribed on the sherd reads "To Athena Hygieia. Kallis made it and dedicated it." The dedication of the potter Kallis was inscribed on the shield of a draped female figure who also held a spear, no doubt Athena herself. ${ }^{84}$

The second piece of evidence is the fragmentary inscribed pillar base for a dedication by the potter Euphronios, probably from the early fifth century BCE. The dedication by Euphronios kerameus is accompanied by four very fragmentary

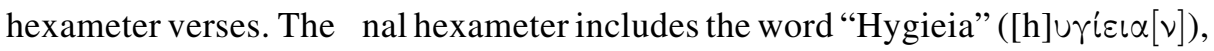
preceded by five missing letters and ] $\alpha \nu$; Sara Aleshire suggested the restoration "Athena Hygieia" ([A $\theta \varepsilon \nu \alpha i] \alpha \nu[h] \cup \gamma i \varepsilon l \alpha[\nu])$. Aleshire's restoration envisions a dedication to Athena Hygieia even though her name would appear in the accusative case rather than the normal dative ("to Athena Hygieia") we find on the base for Pyrrhos' statue. To make the restoration work, we must reconstruct a prayer naming Athena Hygieia rather than a claim that the statue Euphronios dedicated represented Athena Hygieia: at this date, the dedicatory formulas inscribed on statue bases did not name the subject of the statue in the accusative. ${ }^{85}$ The problem is that Aleshire's restoration does not fit the inscribed epigram's hexametric meter. A more plausible explanation for the appearance of the word "hygieia" in Euphronios' fragmentary epigram is that his dedication took the form of a generalized prayer to preserve his health, or even the "health" of his pots. ${ }^{86}$

On its own, the use of the epithet Hygieia for Athena on the dedication of the red-figure potter Kallis is not enough to support the existence of a cult place for Athena Hygieia on the Acropolis earlier in the fifth century; after all, not all epithets of the gods inscribed upon votive dedications necessarily corresponded with "cults" per se. Additional "proof" for an early Athena Hygieia cult has been sought in Plutarch's remark, quoted above, that the Athenians of his own time said that the altar of Athena Hygieia on the Acropolis was there before the statue; Aelius Aristides in the second century CE also noted that "the most ancient Athenians erected an altar to Hygieia Athena" (Or. 37.20). It should come as no surprise that Athenians in the time of Plutarch and Aristides considered the altar of Athena Hygieia on the Acropolis to be older than the fifth-century Propylaia of Mnesikles. It was oriented farther south than Pyrrhos' statue, and apparently faced east rather than west toward the statue, a circumstance leading Frazer to

84. For a drawing of the sherd, see Wolters 1891: 154; the date comes from Graef and Langlotz 1925-1933: 119, no. 1367, and plate 91, and Beazley 1963: 1556. For incised signatures on Athenian pottery and their significance, see Cohen 1991a. $\mathrm{I}^{3} 824$.

85. Aleshire 1989: 11-12, followed by Shapiro 1993: 125; cf. Hansen 1983: no. 271 and IG

86. See Keesling 2003: 134-35. The Epidauros cure texts (IG IV ${ }^{2}$ 121, 11. 79-89) include the story of slave who broke his master's cup and took it to the sanctuary of Asklepios where the god miraculously restored it. 
conclude that an earlier "cult" statue of Athena Hygieia originally stood east of the altar, only to be replaced after the construction of the Propylaia by the "votive" image dedicated by the Athenians. Yet there is simply no evidence for an earlier statue on the Acropolis, and the altar as it stands appears to be contemporary with the statue made in the fifth century by Pyrrhos. ${ }^{87}$ A persistent desire to date the cult of Athena Hygieia on the Acropolis earlier, which goes back at least to the Roman imperial period, could be obscuring the true nature of what was in fact a new cult foundation of the fifth century BCE.

Wolters' plague hypothesis has been widely accepted, and as a consequence little effort has been made to determine the origin of Plutarch's aition for the statue of Athena Hygieia. I would suggest that the story of the workman arose as an explanation for the unusually close physical association between Pyrrhos' statue of Athena Hygieia and the Propylaia. ${ }^{88}$ The form iconatrophy took in this case was a misreading of the significance of the statue's location under the eaves of the roof of the Propylaia, which the Monument-Novelle successfully explained as marking the spot where a workmen fell during the building's construction. ${ }^{89}$ The workman's

87. Altars without inscriptions are difficult to date. Judeich (1931: 242-44) considered the construction technique of the altar east of the Athena Hygieia statue to be consistent with a date in the last quarter of the fifth century; the crown and base moldings (Wolters 1891: 160-62 and plate VI, nos. 6 and 7), though not quite identical to those of the statue base (nos. 4 and 5), are still comparable to fifth-century examples (illustrated and discussed by Mark 1993: 59-61 and fig. 13). The objection that the sacrificer on this altar would have to face east rather than west toward the statue, used to argue for an earlier, Archaic altar and cult statue (by Michaelis 1876: 293-94; Frazer 1898: 280; Ashmole 1927: 7-8; and Brouskari 1997: 232-33), is not conclusive. Though in scenes of sacrifice in vase painting the altar "faces" the statue (e.g. de Cesare 1997: figs. 42, 108, and 133), temple altars were not always oriented such that the sacrificer faced the temple and cult statue; as a case in point, the main altar of Athena on the Acropolis is normally restored in such a way that the sacrificer faced east. The offering table in front of Pyrrhos' Athena Hygieia statue, though uninscribed and impossible to date, must have been put in place after the statue because, unlike the statue base and the altar, it does not rest directly on the Acropolis bedrock (Wolters 1891: 162 and plate VI, no, 2).

88. Parallels prove difficult to find because the normal placement of temple columns on a threestep crepidoma made it impossible to put a monument base as close to a column as the Athena Hygieia base is to the Propylaia corner column. One Athenian parallel does stand out: a herm dedicated by an archon basileus named Onesippos sits on the lower step of the crepidoma just in front of the northernmost column of the Stoa Basileios in the Agora. Onesippos, unlike the other basileis who set up offerings in and around the Stoa, made his dedication while still in office. Edmonson (1982) explained the herm as a commemoration of a choregic victory in $403 \mathrm{BCE}$, just after the restoration of the Athenian democracy. Other examples of monument bases erected directly in front of temple and stoa columns seem to date much later: the bases in front of the Heraion at Olympia date to the Roman period (Eckstein 1969: 93-97 and plate 4), and the equestrian base in front of the one of the columns of the fifth-century Athenian Stoa at Delphi dates to the second century BCE (Siedentopf 1968: 50, fig. 9 and 109-10). Cf. the multiple bases lined up along the façades of stoas in the agora of Thasos (Grandjean and Salviat 2000: fig. 12, nos. 27 and 36) and the monument bases at the northwest corner of the Parthenon (Korres 1994).

89. Cf. Robertson 1999: 176-77: "the story may have arisen almost as soon as the statue was erected, for it conveys a lesson of contemporary interest, that Athena herself gave assistance in the construction of the Propylaea." For a modern iconatrophic anecdote about the Propylaia, see Ridgway 2001. 
miraculous healing by Athena explained why Pyrrhos' statue was dedicated to Athena with the epithet "Health." The dedicatory inscription naming Athena Hygieia as the recipient deity probably remained legible throughout antiquity, but this inscription did not mention the Thucydidean plague or any other historical occasion..$^{90}$ If the statue was dedicated as a result of the plague, this occasion might have been effectively displaced from Athenian collective memory by the introduction of the cult of Asklepios and the personification of Hygieia to Athens a few years later, in 420/19 BCE.

By the time of Pliny, both the identity and the location of the Splanchnoptes of Styppax may also have required further explanation. The aition as it appears in Pliny implies a location for that statue near the Parthenon, and perhaps also near the portrait of Perikles seen by Pausanias, a location that would have encouraged the Splanchnoptes' identification as Perikles' slave. The portrait statue of Perikles on the Acropolis, whether it stood near the colossal bronze Athena of Pheidias in front of the west end of the Old Athena temple, or near the northwest corner of the Propylaia, would have been within sight of the statue of Athena Hygieia, encouraging the reinterpretation of the Athena Hygieia as a dedication made on the initiative of Perikles rather than by the Athenian demos as the inscribed base says. ${ }^{91}$ The spatial interrelationships between an entire series of surviving fifthcentury votive monuments on the Athenian Acropolis thus may have sufficed to inspire the oral traditions recorded in the Roman imperial period by Pliny and Plutarch.

\section{CONCLUSION}

The Roman imperial period-and in particular the so-called Second Sophistic-was a time of unparalleled interest in Greek sanctuaries and their monuments. It would be simply impossible to study either the history of Greek sanctuaries or the history of Greek sculpture without some degree of reliance upon testimonia

90. Pausanias' association of other statues in Athens (but not the Athena Hygieia) with the fifth-century plague runs into the same sort of objection: their votive inscriptions are unlikely to have named the plague as the occasion for their dedication. It is natural that fifth-century monuments such as the statue of Apollo Alexikakos ("averter of ill") by Kalamis in the Athenian Agora (Paus. 1.3.4) would have come over the course of time to be associated with Thucydides' plague; in this particular case, the date of the sculptor Kalamis (discussed above) may rule out the association. Other buildings and statues associated with the great plague by Pausanias are the sanctuary of Pan Lyterios at Troizen (2.32.6), the temple of Apollo Epikourios at Bassai (8.41.8-9), and the bronze he-goat dedicated by the people of Kleonai at Delphi (10.11.5). For Athenian responses to the plague, including the foundation of the cult of Asklepios, see Mikalson 1984 and Miles 1989: 227-35.

91. The portrait of Perikles and the Athena Lemnia by Pheidias are the last statues mentioned by Pausanias (1.28.2) in his periegesis of the Acropolis. Location near the northeast corner of the Propylaia: Stevens 1936: 511-15 and fig. 63; location either there or near the colossal bronze Athena: Hölscher 1988: 380-81. Cf. Robertson (1999), who connects the Splanchnoptes with the cult of Athena Hygieia. 
written during this period. But we should not assume that such testimonia may be used to recover the original meanings of sculptural monuments of the Archaic and Classical periods in Greek sanctuaries. Non-specific or unfamiliar iconography and poses, the loss of hand-held attributes and other sorts of damage to statues over time, unusual sculptural placements, and later rearrangements of votive dedications within sanctuaries all posed problems for later observers seeking to understand earlier Greek sculpture. The chief obstacles to the preservation of authentic memories, however, may have been the original dedicatory texts inscribed on the bases of votive statues: these typically included the dedicator's and sculptor's names, but not the statue's subject or the occasion behind its dedication in the sanctuary. Paradoxically, the monuments dedicated in the Archaic and Classical periods sought through their inscriptions and their apparent topographical fixity to convince viewers that they were fixed points of historical reference, but this appearance of unbroken historical continuity is an illusion: the oldest dedications, those of greatest interest to second sophistic authors such as Pausanias and Plutarch, were at the same time potentially the most unstable in their meanings.

Much of the Roman experience of Greek sculpture in the late Roman Republic and the empire was decontextualized; some important Greek works were reinterpreted as a result of being taken to Rome and displayed in public galleries or private villas. ${ }^{92}$ Here I suggest that even the Greek originals that continued to be viewed in their original settings in Greece were subject to significant reinterpretation over time. Statues without preserved or legible inscriptions were probably the most unstable, but even intact monuments with preserved votive inscriptions left "gaps" filled over time by oral traditions. The three examples discussed here fall within the definition of iconatrophy, one specific process of oral tradition by which new stories arise as explanations for old monuments that (for whatever reason) no longer make sense to their viewers. Iconatrophy and other "deformations" of oral tradition were possible even within much shorter intervals than the five hundred to seven hundred years elapsed between the votive statues of the Archaic and Classical periods and Roman imperial observers. ${ }^{93}$

Encounters with foreign cultures and their monuments-for example, the so-called Colossi of Memnon in Egypt — continued to be a source of iconatrophic oral traditions and Monument-Novellen in the Roman imperial period just as they

92. On Roman collecting and its consequences, see Bergmann 1995: 87-94.

93. Wiseman (1986) argues that monuments dating to the early and middle Republic in Rome were subject to misinterpretation as little as 200 years after the fact; see, in a similar vein, Cooley (2000) on inscribed monuments on the Capitoline. The case of the portrait of Cloelia in the Roman Forum is particularly suggestive of iconatrophy: what appeared in the late Republic to be an equestrian portrait of a woman wearing a toga was interpreted as a representation of an early Republican woman named Cloelia (Livy 2.13.6-11 and Pliny HN 34.28-29; see Wiseman 1986: 89). In the Renaissance, the male "Camillus" type in Roman sculpture was popularly called La Zingara, "the gypsy woman" (Barkan 1999: 166-69). 
were for Herodotus in the fifth century BCE. ${ }^{94}$ But similar encounters occurred much closer to the geographic and cultural center of the Roman empire, and in some cases they displaced "authentic" older memories, a source of historical discontinuity in Greco-Roman antiquity that has gone largely unacknowledged in recent Classical archaeology. ${ }^{95}$ The chronological distance between Milo of Croton in the sixth century $\mathrm{BCE}$ and Philostratos in the third century $\mathrm{CE}$ is in fact comparable to the gulf separating the Roman "Horse tamers" from their Renaissance interpreters. To some extent, iconatrophy was just as inevitable when statues stood in the same place in Greece for centuries as when they were removed to Rome. Yet the currency of iconatrophic Monument-Novellen generated by Greek statues in the Roman empire should not be viewed in an entirely negative light: such stories were repeated as a direct result of their explanatory force and their ability to make ancient monuments meaningful to a new audience. The Greek originals esteemed so highly by modern scholarship on Greek sculpture were not always able to speak for themselves.

Georgetown University keeslinc@georgetown.edu

\section{BIBLIOGRAPHY}

Alcock, S. E. 1996. "Landscapes of Memory and the Authority of Pausanias." In Pausanias historien, Fondation Hardt, Entretiens sur l'antiquité classique XLI, 241-76. Geneva.

- 2001a. Archaeologies of the Greek Past: Landscape, Monuments, and Memories. Cambridge.

- 2001b. "The Reconfiguration of Memory in the Eastern Roman Empire." In S. E. Alcock et al., eds., Empires: Perspectives from Archaeology and History, 32350. Cambridge.

Aleshire, S. B. 1989. The Athenian Asklepieion: The People, their Dedications, and the Inventories. Amsterdam.

Amandry, P. 1957. "A propos de Polyclète. Statues d'olympioniques et carrières de sculpteurs." In K. Schauenburg, ed., Charites, Studien zur Altertumswissenschaft E. Langlotz gewidmet, 63-87. Bonn.

Arafat, K. W. 1996. Pausanias' Greece, Ancient Artists and Roman Rulers. Cambridge. _. 2000. "The Recalcitrant Mass: Athenaeus and Pausanias." In D. Braund and J. Wilkins, eds., Athenaeus and his World: Reading Greek Culture in the Roman Empire, 191-202. Exeter.

Arnold, D. 1969. Die Polykletnachfolge: Untersuchungen zur Kunst von Argos und Sikyon zwischen Polyklet und Lysipp. Berlin.

Ashmole, B. 1927. "Hygieia on Acropolis and Palatine." PBSR 10: 1-11.

94. For the Colossi of Memnon in the Roman period, see Bowersock 1984.

95. One important exception is Alcock's (2001b: 334-38 and 2001a: 36-73) discussion of the early imperial reconfiguration of monumental spaces such as the Athenian Agora into "memory theaters." 
Barkan, L. 1993. “The Beholder's Tale: Ancient Sculpture, Renaissance Narratives." Representations 44: 133-66.

- 1999. Unearthing the Past: Archaeology and Aesthetics in the Making of Renaissance Culture. New Haven and London.

Baumer, L. 1997. Vorbilder und Vorlagen. Studien zu klassischen Frauenstatuen und ihrer Verwendung für Reliefs und Statuetten des 5. und 4. Jahrhunderts vor Christus. Bern.

Beazley, J. D. 1963. Attic Red-Figure Vase Painters. 2nd ed. Oxford.

Bergmann, B. 1995. "Greek Masterpieces and Roman Recreative Fictions." HSCP 97: $79-120$.

Boardman, J. 1986. "Leaina.” In H. A. G. Brijder, A. D. Drukker, and C. W. Neeft, eds., Enthousiasmos. Essays on Greek and Related Pottery Presented to J. M. Hemelrijk, 93-96. Amsterdam.

Bötticher, C. 1856. "Die Attribute des Herabildes zu Argos und der Nike Apteros zu Athen." AZ 14: 175-76.

Bohn, R. 1880. "Zur Basis der Athena Hygieia." AM 5: 331-34.

Bohringer, F. 1979. "Cultes d'athlètes en grèce classique: propos politiques, discours mythiques." REA 81: 5-18.

Boureau, A. 2001. The Myth of Pope Joan. Trans. L. G. Cochrane. Chicago.

Bowersock, G. 1984. “The Miracle of Memnon.” BASP 21: 21-32.

Bowie, E. L. 1978. “Apollonius of Tyana: Tradition and Reality.” ANRW II 16.2: 1652 99.

- 1996. "Past and Present in Pausanias." In Pausanias historien, Fondation Hardt, Entretiens sur l'antiquité classique XLI, 207-39. Geneva.

Brouskari, M. 1997. The Monuments of the Acropolis. Athens.

Burkert, W. 1994. "Olbia and Apollo of Didyma: A New Oracular Text." In J. Solomon, ed., Apollo: Origins and Influences, 49-60. Tuscon.

Chamoux, F. 1979. "Le monument de Théogénès: Autel ou statue?" In Thasiaca, BCH supplement V, 143-53. Paris and Athens.

_ 1991. "La génisse d'Herculanum. Un aspect de la sculpture animalière chez les Grecs." MMAI 72: 9-32.

Cohen, B. 1991a. "The Literate Potter: A Tradition of Incised Signatures on Attic Vases." MMAJ 26: 49-95.

. 1991b. "Perikles' Portrait and the Riace Bronzes: New Evidence for 'Schinocephaly."” Hesperia 60: 465-502.

Connolly, A. 1998. "Was Sophocles Heroised as Dexion?" JHS 118: 1-21.

Cooley, A.E. 2000. "Inscribing History at Rome." In A.E. Cooley, ed., The Afterlife of Inscriptions: Reusing, Rediscovering, Reinventing and Revitalizing Ancient Inscriptions, BICS supplement 75, 7-20. London.

Currie, B. 2002. "Euthymos of Locri: A Case Study of Heroisation in the Classical Period." JHS 122: 24-44.

Davies, J. K. 2000. “Athenaeus' Use of Public Documents.” In D. Braund and J. Wilkins, eds., Athenaeus and his World: Reading Greek Culture in the Roman Empire, 203-17. Exeter.

Day, J. W. 1994. "Interactive Offerings: Early Greek Dedicatory Epigrams and Ritual." HSCP 96: 37-74.

de Cesare, M. 1997. Le statue in immagine. Studi sulle raffigurazioni di statue nella pittura vascolare greca. Rome. 
Delivorrias, A. 1978. "Das Original der sitzenden 'Aphrodite-Olympias." AM 93: 1-23.

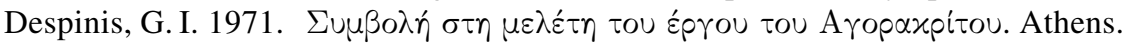

Dittenberger, W., and K. Purgold. 1896. Die Inschriften von Olympia. Olympia V. Berlin.

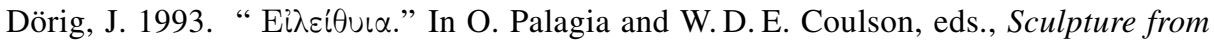
Arcadia and Laconia, 145-51. Oxford.

Ebert, J. 1972. Griechische Epigramme auf Sieger an gymnischen und hippischen Agonen. Berlin.

Eckstein, F. 1969. Anathemata. Berlin.

Edmonson, C. 1982. “Onesippos' Herm.” In Studies in Attic Epigraphy, History and Topography Presented to Eugene Vanderpool, Hesperia supplement XIX, 48-50. Princeton.

Elsner, J. 1997. "Hagiographic Geography: Travel and Allegory in the Life of Apollonios of Tyana." JHS 117: 22-37.

Evans, J. A. S. 1991. Herodotus, Explorer of the Past. Princeton.

Fehling, D. 1989. Herodotus and his "Sources." Citation, Invention and Narrative Art. Trans. J. G. Howie. German original: Die Quellenangaben bei Herodot (Berlin and New York, 1971). Leeds.

Figueira, T. J. 1993. "Herodotus on the Early Hostilities between Aigina and Athens." In Excursions in Epichoric History, 35-60. Lanham, Md.

Fittschen, K. 1991. "Zur Rekonstruktion griechischer Dichterstatuen 1. Die Statue des Menander." AM 106: 243-79.

Flower, H. I. 1991. "Herodotus and Delphic Traditions about Croesus." In M. A. Flower and M. Toher, eds., Georgica, Greek Studies in Honour of George Cawkwell, BICS Supplement 58, 57-77. London.

Fontenrose, J. 1968. "The Hero as Athlete." CSCA 1: 74-104.

Forrest, W. G. 1995. “Aristophanes, Lysistrata 231.” CQ n.s. 45: 240-41.

Frazer, J. G. 1898. Pausanias's Description of Greece. 6 vols. London.

Fuchs, W. 1995. "In Search of Herodotus' Poseidon at the Isthmus." Thetis 2: 73-78.

Gabba, E. 1981. "True History and False History in Classical Antiquity." JRS 71: 50-62.

Garrett, A., and L. Kurke. 1994. "Pudenda Asiae Minoris." HSCP 96: 75-83.

Geagan, D. 1996. "Who was Athena?” In M. Dillon, ed., Religion in the Ancient World, New Themes and Approaches, 145-64. Amsterdam.

Ghisellini, E. 1988. "La statua di Milone di Crotone ad Olimpia.” Xenia 16: 43-52.

Gow, A. S. F. 1965. Machon, The Fragments. Cambridge.

Graef, B., and E. Langlotz. 1925-1933. Die antiken Vasen von der Akropolis zu Athen. Berlin.

Grandjean, Y., and F. Salviat. 2000. Guide de Thasos. 2nd ed. Paris and Athens.

Gross, W. H. 1988 [originally published 1969]. “'Quas iconicas vocant': Zum Porträtcharakter der Statuen dreimaliger olympischer Sieger." In K. Fittschen, ed., Griechische Porträts, 359-74. Darmstadt.

Habicht, C. 1984. "Pausanias and the Evidence of Inscriptions." ClAnt 3: 40-56.

Hackländer, N. 1997. "Der Betende Knabe-Eine Antike auf Wanderschaft." In G. Zimmer and N. Hackländer, eds., Der Betende Knabe, Original und Experiment, 25-34. Frankfurt.

Hansen, P. A. 1983. Carmina Epigraphica Graeca, saeculorum VIII-V a. Chr. $n$. Berlin and New York.

— . 1989. Carmina Epigraphica Graeca, saeculi IV a. Chr. n. (CEG 2). Berlin and New York. 
. 1990. "Diogenes the Cynic at Venice." ZPE 82: 198-200.

Harrison, E. B. 1988. "Lemnia and Lemnos: Sidelights on a Pheidian Athena." In Kanon, Festschrift Ernst Berger, 101-107. AntK Beiheft 15. Basel.

Haskell, F., and N. Penny. 1981. Taste and the Antique: The Lure of Classical Sculpture, 1500-1900. New Haven.

Haynes, D. L. 1992. The Technique of Greek Bronze Statuary. Mainz.

Hedrick, C. W., Jr. 1993. "The Meaning of Material Culture: Herodotus, Thucydides, and their Sources." In R. M. Rosen and J. Farrell, eds., Nomodeiktes. Greek Studies in Honor of Martin Ostwald, 17-37. Ann Arbor.

- 1995. "Thucydides and the Beginnings of Archaeology." In D. Small, ed., Methods in the Mediterranean, 45-88. Leiden.

Henige, D. 1982. Oral Historiography. London.

Herrmann, H.-V. 1988. "Die Siegerstatuen von Olympia. Schriftliche Überlieferung und archäologischer Befund." Nikephoros 1: 119-83.

Higbie, C. 2001. "Homeric Athena in the Chronicle of Lindos." In S. Deacy and A. Villing, eds., Athena in the Classical World, 105-25. Leiden.

. 2003. The Lindian Chronicle and the Greek Creation of their Past. Oxford.

Hölscher, T. 1988 [originally published 1973]. "Die Aufstellung des Perikles-Bildnisses und ihre Bedeutung." In K. Fittschen, ed., Griechische Porträts, 377-91. Darmstadt.

Hurwit, J. M. 1985. The Art and Culture of Early Greece, 1100-480 B.C. Ithaca.

. 1999. The Athenian Acropolis. History, Mythology, and Archaeology from the Neolithic Era to the Present. Cambridge.

Hyde, W. W. 1921. Olympic Victor Monuments and Greek Athletic Art. Washington.

Jacoby, F. 1949. Atthis, The Local Chronicles of Ancient Athens. Oxford.

Jacquemin, A. 1999. Offrandes monumentales à Delphes. BEFAR 304. Paris and Athens. Jameson, M. H. 1953. "Inscriptions of the Peloponnese." Hesperia 22: 148-71.

Jeffery, L. H. 1949. “Comments on Some Archaic Greek Inscriptions.” JHS 69: 25-38.

. 1990. Local Scripts of Archaic Greece. Revised by A. W. Johnston. Oxford.

Jex-Blake, K., and E. Sellers. 1896. The Elder Pliny's Chapters on the History of Art. London.

Jones, C. P. 2001. "Pausanias and his Guides.” In S. E. Alcock, J. F. Cherry, and J. Elsner, eds., Pausanias, Travel and Memory in Roman Greece, 33-39. Oxford.

Judeich, W. 1931. Topographie von Athen. 2nd ed. Munich.

Karanastassis, P. 1987. "Untersuchungen zur kaiserzeitlichen Plastik in Griechenland II: Kopien, Varianten und Umbildungen nach Athena-Typen des 5. Jhs. v. Chr." AM 102: 323-428.

Keesling, C. M. 2003. The Votive Statues of the Athenian Acropolis. Cambridge and New York.

Kinney, D. 1997. “Spolia: Damnatio and Renovatio Memoriae." MAAR 42: 117-48.

Kissas, K. 2000. Die attischen Statuen- und Stelenbasen archaischer Zeit. Bonn.

Korres, M. 1994. "Recent Discoveries on the Acropolis." In R. Economakis, ed., Acropolis Restoration, The CCAM Interventions, 174-79. London.

Kozloff, A. P., and D. G. Mitten. 1988. The Gods Delight. The Human Figure in Classical Bronze. Cleveland.

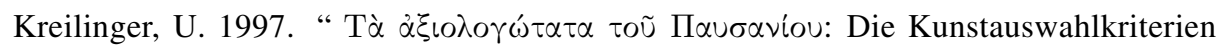
des Pausanias." Hermes 125: 470-91.

Kron, U. 1977. "Eine Pandion-Statue in Rom, mit einem Exkurs zu Inschriften auf Plinthen." JdI 92: 139-68. 
Krumeich, R. 1997. Bildnisse griechischer Herrscher und Staatsmänner im 5. Jahrhundert v. Chr. Munich.

Kurke, L. 1999. Coins, Bodies, Games, and Gold. The Politics of Meaning in Archaic Greece. Princeton.

Kyrieleis, H. 1995. "Eine neue Kore des Cheramyes." AntP 24: 7-36.

Lacroix, L. 1992. “À propos des offrandes à l'Apollon de Delphes et du témoinage de Pausanias: Du réel à l'imaginaire." BCH 116: 157-76.

Lattimore, S. 1988. "The Nature of Early Greek Victor Statues.” In S. J. Bandy, ed., Coroebus Triumphs, 245-56. San Diego.

Lawton, C. 1995. Attic Document Reliefs. Oxford.

Lazzarini, M. L. 1976. Le formule delle dediche votive nella Grecia arcaica. MemLinc ser. 8, no. 19.ii. Rome.

— . 1984-1985. "Epigrafia e statua ritratto: alcuni problemi." AAPat 97: 83-103.

— 1989-1990. "Iscrizioni votive greche." SCAnt 3-4: 845-59.

Lefkowitz, M. R. 1978. "The Poet as Hero: Fifth-century Autobiography and Subsequent Biographical Fiction." CQ 28: 459-69.

Lewis, D. M., and R.S. Stroud. 1979. "Athens Honors King Euagoras of Salamis." Hesperia 48: 180-93.

Linfert, A. 1978. "Die Propyläen der Akropolis von Athen-Ein Dach für Viele." AM 93: 25-34.

Lloyd, A. B. 1988. Herodotus, Book II, Commentary. Leiden.

Loewy, E. 1885. Inschriften griechischer Bildhauer. Leipzig.

Maddoli, G., M. Nafissi, and V. Saladino. 1999. Pausania, Guida della Grecia, Libro VI: L'Elide e Olimpia. Milan.

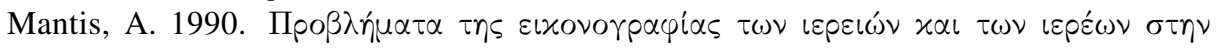

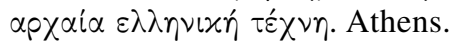

Marcadé, J. 1985. "La polyvalence de l'image dans la sculpture grecque." In Eidolopoïa, Actes du colloque sur les problèmes de l'image dans le monde méditerranéen classique, 27-39. Rome.

Marincola, J. 1987. "Herodotean Narrative and the Narrator's Presence." Arethusa 20: 121-37.

Mark, I. S. 1993. The Sanctuary of Athena Nike in Athens, Architectural Stages and Chronology. Hesperia supplement XXVI. Princeton.

Mattusch, C.C. 1988. Greek Bronze Statuary from the Beginnings through the Fifth Century B.C. Ithaca.

- 1996. The Fire of Hephaistos, Large Classical Bronzes from North American Collections. Cambridge, Mass.

. 2002. "A Note on the Apoxyomenos of Vele Orjule." Minerva 13: 49-50.

Merkelbach, R., and J. Stauber, eds. 2001. Steinepigramme aus dem griechischen Osten, vol. 2: Die Nordküste Kleinasiens (Marmarasee und Pontos). Munich and Leipzig.

Michaelis, A. 1876. "Bemerkungen zur Periegese der Akropolis von Athen." AM 1: 275-307.

Mikalson, J.D. 1984. "Religion and the Plague in Athens, 431-423 BCE" In Studies Presented to Sterling Dow on the Eightieth Birthday, GRBM 10, 217-25. Durham, N.C.

Miles, M. M. 1989. "A Reconstruction of the Temple of Nemesis at Rhamnous." Hesperia 58: 133-249.

Miller, S. G. 1972. “The Colossus of Porto Raphti Reconsidered.” Hesperia 41: 192-97. 
Moretti, L. 1957. Olympionikai, I vincitori negli antiche agoni olimpici. MemLinc ser. 8.2. Rome.

Murray, O. 1987. "Herodotus and Oral History." In A. Kuhrt and H. Sancisi-Weerdenburg, eds., Achaemenid History II: The Greek Sources, Proceedings of the Groningen 1984 Achaemenid History Workshop, 93-115. Leiden.

_ 2001. "Herodotus and Oral History Reconsidered." In N. Luraghi, ed., The Historian's Craft in the Age of Herodotus, 314-25. Oxford.

Neugebauer, K. A. 1931. Staatliche Museen zu Berlin, Die minoischen und archaischen griechischen Bronzen. Katalog der statuarischen Bronzen im Antiquarium, vol. 1. Berlin and Leipzig.

Niemeyer, H. G. 1964. "Attische Bronzestatuetten der spätarchaischen und frühklassischen Zeit." AntP 3: 7-31.

Ogden, D. 1999. Polygamy, Prostitutes, and Death: The Hellenistic Dynasties. London. Palagia, O. 1980. Euphranor. Leiden.

. 1990. "A New Relief of the Graces and the Charites of Socrates." In M. Geerard, ed., Opes Atticae, Miscellanea Philologica et Historica Raymondo Bogaert et Hermanno Van Looy oblata, 347-56. The Hague.

— 1994. "No Demokratia." In W. D. E. Coulson et al., eds., The Archaeology of Athens and Attica under the Democracy, 113-22. Oxford.

Pardoe, R., and D. Pardoe. 1988. The Female Pope: The Mystery of Pope Joan. Wellingborough, Northamptonshire.

Parke, H. W. 1984. "Croesus and Delphi." GRBS 25: 209-32.

Philipp, H., and W. Koenigs. 1979. "Zu den Basen des L. Mummius in Olympia.” AM 97: 193-216.

Pirenne-Delforge, V. 1994. L'Aphrodite grecque. Kernos supplement 4. Athens and Liège.

Pouilloux, J. 1994. "Théogénès de Thasos...quarante ans après." BCH 118: 199-206.

Raubitschek, A. E. 1949. Dedications from the Athenian Akropolis. Cambridge, Mass. . 1991 [originally published 1943]. "An Original Work of Endoios.” In D. Obbink and P. A. Van der Waerdt, eds., The School of Hellas, Essays on Greek History, Archaeology, and Literature, 212-19. Oxford.

Reisch, E. 1890. Griechische Weihgeschenke. Vienna.

Richter, G. M. A. 1970. Kouroi, Archaic Greek Youths. 3rd ed. London and New York.

Ridder, A. de. 1896. Catalogue des bronzes trouvés sur l'Acropole d'Athènes. BEFAR 74. Paris.

Ridgway, B.S. 1992. "Images of Athena on the Akropolis." In J. Neils, ed., Goddess and Polis: The Panathenaic Festival in Ancient Athens, 119-42. Princeton.

— 1995. "Paene ad exemplum: Polykleitos' Other Works." In W. G. Moon, ed., Polykleitos, the Doryphoros, and Tradition, 177-99. Madison.

_ 2001. "Some Personal Thoughts on the Knidia." In N. Birkle et al., eds., Macellum: Culinaria archaeologica, Robert Fleischer zum 60. Geburtstag von Kollegen, Freunden und Schulern. (Electronic publication.) Mainz.

. 2002. Hellenistic Sculpture III: The Styles of ca. 100-31 BCE Madison.

Ritti, T. 1973-1974. "L'uso di 'Immagini Onomastiche' nei monumenti sepolcrali di età greca." ArchCl 25-26: 639-60.

Robertson, N. 1996. "Athena's Shrines and Festivals." In J. Neils, ed., Worshipping Athena, 27-77. Madison.

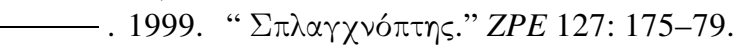


Russmann, E. R. 1981. “An Egyptian Royal Statuette of the Eighth Century BCE” In W. K. Simpson and W. M. Davis, eds., Studies in Ancient Egypt, the Aegean, and the Sudan. Essays in Honor of Dows Dunham, 149-55. Boston.

Rutherford, I. 2001. "Tourism and the Sacred: Pausanias and the Traditions of Greek Pilgrimage." In S. E. Alcock, J. F. Cherry, and J. Elsner, eds., Pausanias, Travel and Memory in Roman Greece, 40-52. Oxford.

Saller, R. 1980. "Anecdotes as Historical Evidence for the Principate." Greece and Rome 27: 69-83.

Scarfi, B. M. 1990. The Lion of Venice, Studies and Research on the Bronze Statue in the Piazzetta. Venice.

Scherer, C. 1885. De olympionicarum statuis. Diss. Göttingen.

Schrader, H., ed. 1939. Die archaischen Marmorbildwerke der Akropolis. Frankfurt.

Serwint, N. J. 1987. Greek Athletic Sculpture from the Fifth and Fourth Centuries BCE: An Iconographic Study. Diss. Princeton.

Shapiro, H. A. 1988. "The Marathonian Bull on the Athenian Akropolis." AJA 92: 37382.

. 1993. Personifications in Greek Art. The Representation of Abstract Concepts, 600-400 B.C. Kilchberg and Zurich.

Siedentopf, H. B. 1968. Das hellenistiche Reiterdenkmal. Waldsassen, Bavaria.

Sinn, U. 1989. " "Die Votivgabe eines Athleten in Olympia.” In H.-U. Cain, H. Gabelmann, and D. Salzmann, eds., Festschrift für Nikolaus Himmelmann, 65-70. Mainz.

Spiegelberg, W. 1926. Die Glaubwürdigkeit von Herodots Bericht über Ägypten im Lichte der ägyptischen Denkmäler. Heidelberg.

Stevens, G. P. 1936. "The Periclean Entrance Court of the Acropolis of Athens." Hesperia 5: 443-520.

Stewart, A. 1995. "Notes on the Reception of the Polykleitan Style: Diomedes to Alexander." In W. G. Moon, ed., Polykleitos, the Doryphoros and Tradition, 246-61. Madison.

Studniczka, F. 1899. "Sitzungsberichte der Archäologische Gesellschaft zu Berlin 1899." AA: $130-35$.

Tanoulas, T. 1994. "The Propylaea and the Western Access of the Acropolis." In R. Economakis, ed., Acropolis Restoration, The CCAM Interventions, 52-67. London.

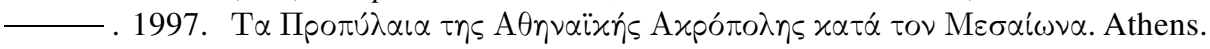

Thilo, G., and H. Hagen. 1887. Servius Grammaticus. 3 vols. Leipzig.

Thomas, Renate. 1981. Athletenstatuetten der spätarchaik und des Strengen Stils. Rome.

Thomas, Rosalind. 1989. Oral Tradition and Written Record in Classical Greece. Cambridge.

Travlos, J. 1971. Pictorial Dictionary of Ancient Athens. New York.

Vansina, J. 1965. Oral Tradition. Chicago.

- 1985. Oral Tradition as History. Madison.

van Straten, F. 1995. Hiera Kala, Images of Animal Sacrifice in Archaic and Classical Greece. Leiden, New York, and Cologne.

Vermeule, C. C. 1962. "The Colossus of Porto Raphti in Attica." Hesperia 31: 62-81.

—. 1972. "Greek Funerary Animals, 450-300 BCE" AJA 76: 49-59.

. 1976. "The Colossus of Porto Raphti: A Roman Female Personification." Hesperia 45: 67-76.

Vermeule, C. C., and P. von Kersburg. 1968. "The Basel Dog: A Vindication, Appendix: Lions, Attic and Related." AJA 72: 95-101. 
Virgilio, B. 1972. " Atleti in Erodoto, tradizione orale e (possibile) tradizione epigrafica." RendIstLomb 106: 451-68.

Ward, R., and P. J. Fidler, eds. 1993. The Nelson-Atkins Museum of Art: A Handbook of the Collection. New York.

Waywell, G. B. 1986. The Lever and Hope Sculptures. Berlin.

West, S. 1985. "Herodotus' Epigraphical Interests.” $C Q$ n.s. 35: 278-305.

. 1991. "Sham Shahs I. Pseudo-Smerdis' Ears." In M. A. Flower and M. Toher, eds., Georgica, Greek Studies in Honour of George Cawkwell, BICS Supplement 58, 176-81. London.

Whitmarsh, T. 2001. Greek Literature and the Roman Empire: The Politics of Imitation. Oxford.

Whittaker, H. 1991. "Pausanias and his Use of Inscriptions." SO 66: 171-86.

Wiseman, T.P. 1986. "Monuments and the Roman Annalists." In I. S. Moxon, J. D. Smart, and A.J. Woodman, eds., Past Perspectives, Studies in Greek and Roman Historical Writing, 87-100. Cambridge.

Wolters, P. 1891. "Zur Athena Hygieia des Pyrros." AM 16: 153-65.

Wycherley, R. E. 1957. Literary and Epigraphical Testimonia. The Athenian Agora III. Princeton.

Zanker, P. 1995. The Mask of Socrates, The Image of the Intellectual in Antiquity. Trans. H. A. Shapiro. Berkeley. 


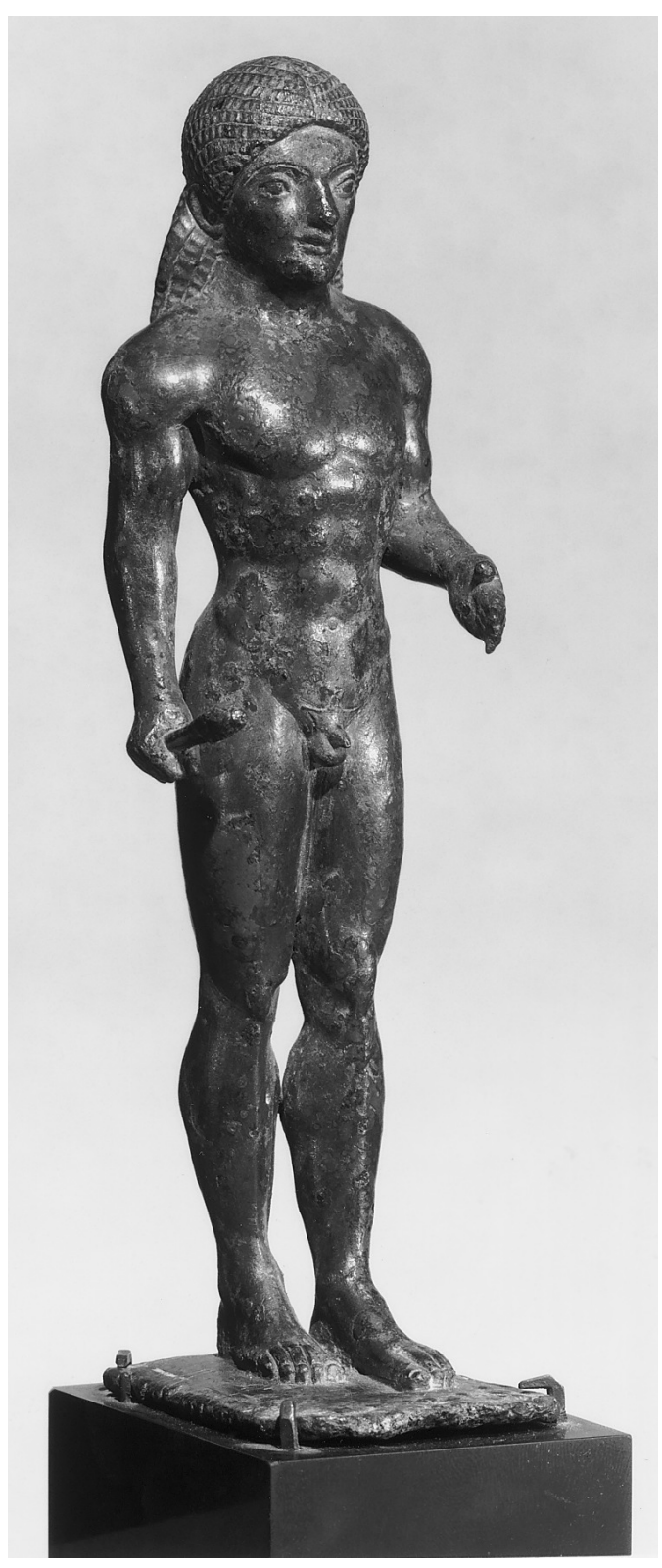

Fig. 1: Small bronze statuette (the "Baker kouros"), ca. 530-520 B.C. The fingers of the left hand are outstretched; the right hand holds an unidentified object. The Metropolitan Museum of Art, Bequest of Walter C. Baker, 1971 (1972.118.101). All rights reserved, The Metropolitan Museum of Art.

Fig. 2: (Facing page.) Reconstruction drawing of the Athenian Acropolis by Gorham P. Stevens, looking eastward through the Propylaia of Mnesikles. On the left, inside the east colonnade of the Propylaia, are the Aphrodite of Kalamis and "Leaina"; at the opposite end of the colonnade the base of the Athena Hygieia of Pyrrhos is partially visible behind the corner column. Beyond the colonnade, the colossal bronze Athena by Pheidias is visible at the west end of the ruined Old Athena temple, between the Erechtheion (left) and the Parthenon (right). After Stevens 1936: frontispiece (courtesy American School of Classical Studies at Athens). 


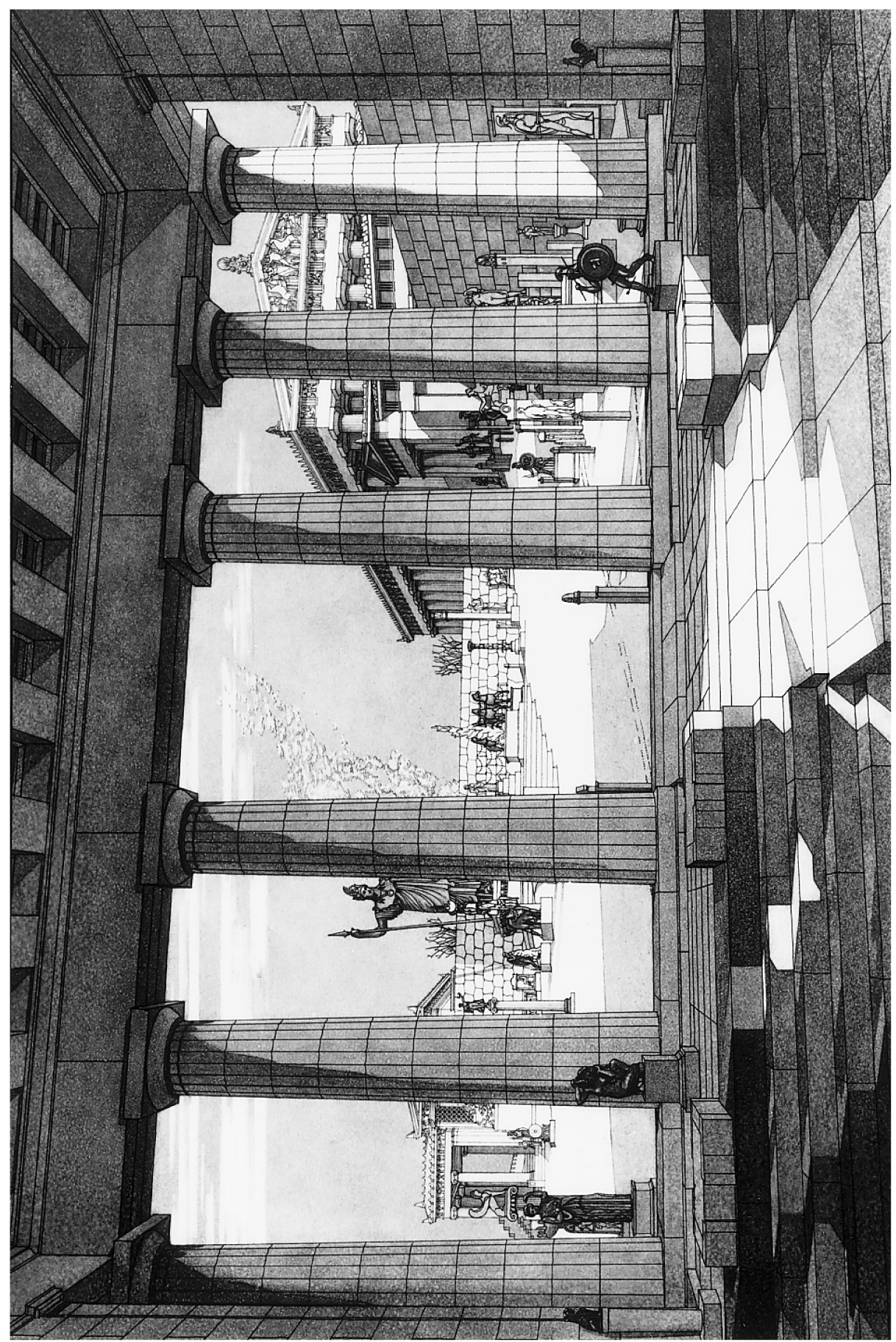




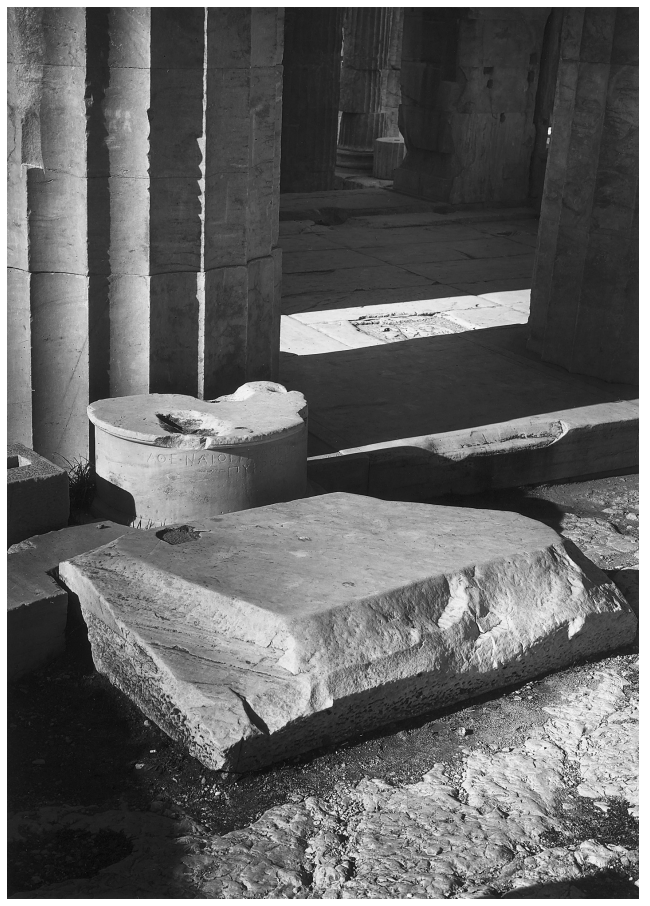

Fig. 3: Base for a lost bronze statue of Athena Hygieia dedicated by the Athenians and signed by Pyrrhos (IG I3 824), shown in situ on the Athenian Acropolis, in front of the southeast corner column of the Propylaia of Mnesikles. The marble base for an offering table stands in front of the statue base. Deutsches Archåologisches Institut neg. Akr. 2435, photo: Hellner.

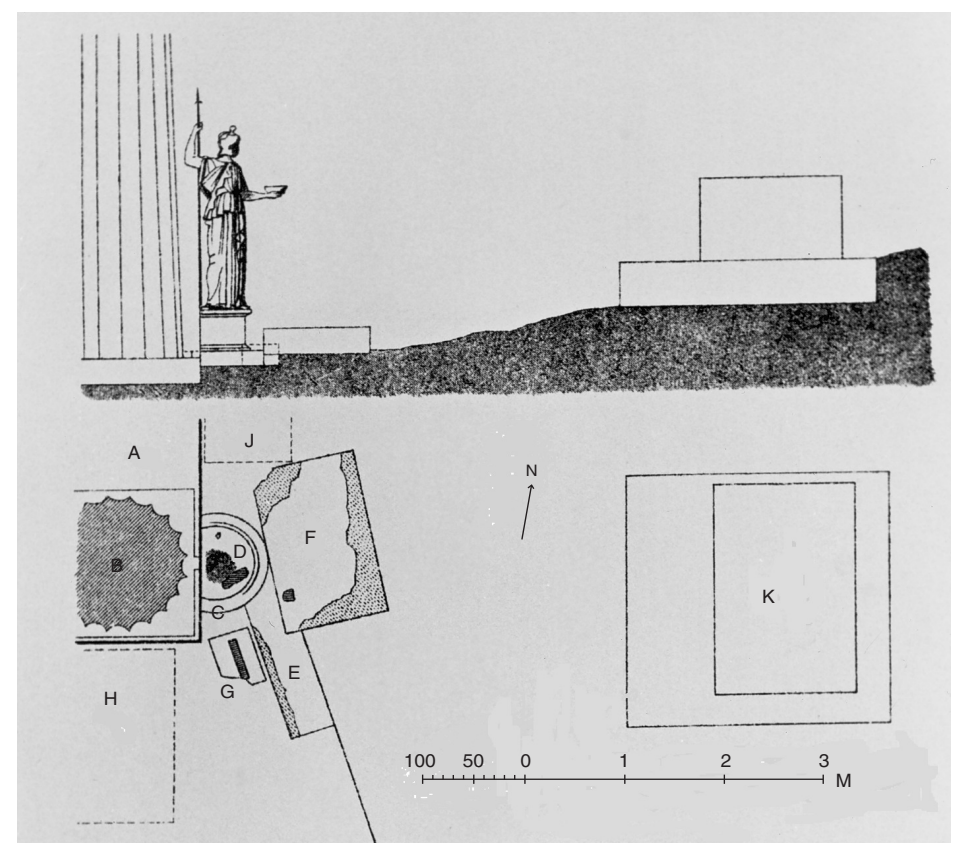

Fig. 4: Top: reconstruction of Pyrrhos' Athena Hygieia statue and the altar of Athena Hygieia on the Acropolis. Bottom: ground plan showing the southeast corner column of the Propylaia (B), the stylobate of the Propylaia (A), the inscribed base for the Athena Hygieia statue (D), the round block underneath the base (C), the base for the offering table $(\mathrm{F})$, and the altar $(\mathrm{K})$. After Michaelis 1876: plate XVI. 